\title{
A reconstruction of atmospheric carbon dioxide and its stable carbon isotopic composition from the penultimate glacial maximum to the last glacial inception
}

\author{
R. Schneider ${ }^{1,2}$, J. Schmitt ${ }^{1,2,3}$, P. Köhler ${ }^{3}$, F. Joos ${ }^{1,2}$, and H. Fischer ${ }^{1,2,3}$ \\ ${ }^{1}$ Climate and Environmental Physics, Physics Institute, University of Bern, Sidlerstrasse 5, 3012 Bern, Switzerland \\ ${ }^{2}$ Oeschger Centre for Climate Change Research, University of Bern, Bern, Switzerland \\ ${ }^{3}$ Alfred Wegener Institute Helmholtz Centre for Polar and Marine Research (AWI), P.O. Box 120161 , \\ 27515 Bremerhaven, Germany \\ Correspondence to: R. Schneider (robert_schneider@posteo.de)
}

Received: 26 March 2013 - Published in Clim. Past Discuss.: 8 April 2013

Revised: 13 September 2013 - Accepted: 26 September 2013 - Published: 6 November 2013

\begin{abstract}
The reconstruction of the stable carbon isotope evolution in atmospheric $\mathrm{CO}_{2}\left(\delta^{13} \mathrm{C}_{\mathrm{atm}}\right)$, as archived in Antarctic ice cores, bears the potential to disentangle the contributions of the different carbon cycle fluxes causing past $\mathrm{CO}_{2}$ variations. Here we present a new record of $\delta^{13} \mathrm{C}_{\mathrm{atm}}$ before, during and after the Marine Isotope Stage 5.5 (155000 to $105000 \mathrm{yr} \mathrm{BP})$. The dataset is archived on the data repository PANGEA ${ }^{\circledR}$ (www.pangea.de) under doi:10.1594/PANGAEA.817041. The record was derived with a well established sublimation method using ice from the EPICA Dome C (EDC) and the Talos Dome ice cores in East Antarctica. We find a $0.4 \%$ shift to heavier values between the mean $\delta^{13} \mathrm{C}_{\mathrm{atm}}$ level in the Penultimate $(\sim 140000 \mathrm{yr}$ BP $)$ and Last Glacial Maximum ( $22000 \mathrm{yr}$ BP), which can be explained by either (i) changes in the isotopic composition or (ii) intensity of the carbon input fluxes to the combined ocean/atmosphere carbon reservoir or (iii) by long-term peat buildup. Our isotopic data suggest that the carbon cycle evolution along Termination II and the subsequent interglacial was controlled by essentially the same processes as during the last $24000 \mathrm{yr}$, but with different phasing and magnitudes. Furthermore, a $5000 \mathrm{yr}$ lag in the $\mathrm{CO}_{2}$ decline relative to EDC temperatures is confirmed during the glacial inception at the end of MIS5.5 (120000 yr BP). Based on our isotopic data this lag can be explained by terrestrial carbon release and carbonate compensation.
\end{abstract}

\section{Introduction}

Various processes are known to influence changes in the carbon distribution and its isotopic signature between the ocean, the atmosphere, terrestrial and marine organic carbon, reactive sediments and the lithosphere. Multiple processes operate simultaneously, and interact with each other non-linearly (Köhler et al., 2005; Brovkin et al., 2007; Sigman et al., 2010; Fischer et al., 2010; Tschumi et al., 2011), allowing for a wide range of possible scenarios to explain observed natural changes in atmospheric $\mathrm{CO}_{2}$. Furthermore, Goodwin et al. (2011) point out that the way in which different climate proxies combine is crucial for accurate past carbon cycle reconstructions. Thus, an unequivocal interpretation of past variations in the global carbon cycle is difficult, but not impossible, if proxy data provide adequate and sufficient constraints. The stable carbon isotope signal of atmospheric $\mathrm{CO}_{2}\left(\delta^{13} \mathrm{C}_{\mathrm{atm}}\right)$ provides a valuable tool to constrain processes affecting the global carbon cycle. Scrutinizing the potential processes and their contributions to the observed $\mathrm{CO}_{2}$ variations, using long-term $\delta^{13} \mathrm{C}_{\mathrm{atm}}$ data sets in conjunction with other proxies like $\left(\delta^{13} \mathrm{C}_{\text {ocean }}\right)$ help disentangle the complex simultaneous changes of processes affecting the carbon cycle in the past. Antarctic ice cores allow for such $\delta^{13} \mathrm{C}_{\text {atm }}$ reconstructions, however, the small changes in $\delta^{13} \mathrm{C}_{\mathrm{atm}}$ demand very high-precision measurements. Furthermore, due to the slow gas enclosure process, atmospheric changes are low-pass filtered in polar ice and fast changes in $\mathrm{CO}_{2}$ and $\delta^{13} \mathrm{C}_{\mathrm{atm}}$ are damped (Joos and Spahni, 2008;

Published by Copernicus Publications on behalf of the European Geosciences Union. 
Köhler et al., 2006, 2010, 2011), where the magnitude of damping is anti-correlated to the temperature and accumulation rate at the particular ice core site. Hence, a measurement precision better than $0.1 \%$ is crucial for $\delta^{13} \mathrm{C}_{\mathrm{atm}}$ data, to provide useful constraints for global carbon cycle variability. Together with the small sample size available in polar ice cores, this represents a formidable analytical challenge. Apart from the requirement for high precision $\delta^{13} \mathrm{C}_{\mathrm{atm}}$ data, long-term coverage becomes crucial, since the balance of silicate and $\mathrm{CaCO}_{3}$ weathering on land and of the preservation and dissolution response of $\mathrm{CaCO}_{3}$, opal and organic carbon in the deep ocean influence the $\mathrm{CO}_{2}$ and $\delta^{13} \mathrm{C}_{\mathrm{atm}}$ dynamics over many thousand years (Elsig et al., 2009; Broecker and Clark, 2003). Since the time constants of these processes are comparable to the pacing of the major climate perturbations acting on orbital scales, neither the ocean's alkalinity budget nor the $\delta^{13} \mathrm{C}$ signature of the reservoirs reach a steady state. Previously published $\delta^{13} \mathrm{C}_{\text {atm }}$ data focused mainly on time periods of distinct changes in atmospheric $\mathrm{CO}_{2}$ including glacial terminations (Lourantou et al., 2010a, b; Schmitt et al., 2012; Smith et al., 1999) or the late rise of the $\mathrm{CO}_{2}$ concentrations in the course of the Holocene (Indermühle et al., 1999; Elsig et al., 2009). Here, we present a new $\delta^{13} C_{a t m}$ record fulfilling the requirements in precision and covering the full Penultimate Glacial Maximum (PGM), the penultimate glacial/interglacial transition, the Marine Isotope Stage (MIS) 5.5, and the following glacial inception to an age of about $105000 \mathrm{yr}$ BP. Our record consists of measurements from two Antarctic ice cores, the European Project for Ice Coring in Antarctica Dome C (EDC) and the Talos Dome ice core. The discussion of these data focuses on four main issues: (1) the critical evaluation of rapid changes in $\delta^{13} \mathrm{C}_{\mathrm{atm}}$ as found by Lourantou et al. (2010b) at the end of the penultimate glacial/interglacial transition; (2) the similarities and differences of this work to the previously documented glacial transition from the Last Glacial Maximum (LGM) to the Holocene (Schmitt et al., 2012); (3) the $5000 \mathrm{yr}$ lag of the $\mathrm{CO}_{2}$ decline with respect to decreasing Antarctic temperature during the glacial inception at the end of MIS5.5; and (4) long-term changes of atmospheric $\delta^{13} \mathrm{C}_{\mathrm{atm}}$.

\section{Materials and methods}

\subsection{Ice core details}

The data presented here were obtained from the EDC $\left(74^{\circ} 39^{\prime} \mathrm{S}, 124^{\circ} 10^{\prime} \mathrm{E}\right.$, elevation $\left.3240 \mathrm{~m}\right)$ and Talos Dome $\left(72^{\circ} 49^{\prime} \mathrm{S}, 159^{\circ} 11^{\prime} \mathrm{E}\right.$, elevation $\left.2315 \mathrm{~m}\right)$ ice cores. EDC samples were taken from depths between 1454 to $1887 \mathrm{~m}$ corresponding to the time interval between 104600 and $154500 \mathrm{yr}$ BP on the EDC3 gas age scale (Parrenin et al., 2007; Loulergue et al., 2007). In total we measured EDC samples at 70 depth intervals, where 44 are single measurements and 26 represent the mean of 2 to 5 replicates from vertically adjacent samples. As the samples are only 5 to $10 \mathrm{~cm}$ apart, they have essentially the same gas composition due to the gas enclosure characteristics, however, the impurity content of the ice phase might be different for those vertical replicates. To improve the robustness of the results and to increase overall temporal resolution, 13 depth intervals from the Talos Dome ice core were analysed, where 6 data points represent single measurements and 7 data points represent replicates. The Talos Dome samples cover a depth range between 1404 and $1444 \mathrm{~m}$ or a time interval from 126000 to $154000 \mathrm{yr}$ BP on the TALDICE-1a gas age scale (where TALDICE-1a is synchronized to the EDC3 age scale via methane synchronization, Schüpbach et al., 2011). At depths where replicate measurements were performed, the error bars in Fig. 1 represent the one $\sigma$ standard deviation, while the mean reproducibility of the respective core was used for single measurements. Here, the mean reproducibility is defined as the average of the one $\sigma$ standard deviation values of depths where replicate measurements were performed. The mean temporal resolution of our combined EDC and Talos Dome $\delta^{13} \mathrm{C}_{\mathrm{atm}}$ record is approximately $600 \mathrm{yr}$.

\subsection{Method details}

To release the air entrapped in Antarctic ice core samples, we used a sublimation extraction and an off-line coupled GCIRMS system described in detail in Schmitt et al. (2011). The $\mathrm{CO}_{2}$ mixing ratio was deduced by measuring the ratio of the air volume released during the sublimation, and the $\mathrm{CO}_{2}$ signal from the mass spectrometer. The mean standard deviation of the $\mathrm{CO}_{2}$ and $\delta^{13} \mathrm{C}_{\mathrm{atm}}$ for the Talos Dome samples measured in this study are approximately $1 \mathrm{ppm}$ and $0.04 \%$, respectively. The $\delta^{13} \mathrm{C}_{\mathrm{atm}}$ precision of our method for Talos Dome is more than a factor of 2 better than other methodologies (Leuenberger et al., 1992; Smith et al., 1999; Lourantou et al., 2010a) and similar as previously measured data on the same ice core with the same method during Termination I (Schmitt et al., 2012). Reproducibility of $\mathrm{CO}_{2}$ and $\delta^{13} \mathrm{C}_{\mathrm{atm}}$ of EDC ice are $3 \mathrm{ppm}$ and $0.08 \%$, which is $1 \mathrm{ppm}$ and $0.02 \%$ o less precise than measurements on shallow bubble ice in the same ice core using the same method (Elsig et al., 2009; Schmitt et al., 2011, 2012). The origin of the higher variability in the deeper EDC ice is unknown but cannot be explained by methodological reasons as standard gas measurements were of usual precisions of $0.06 \%$ or better. The higher air content in the Talos Dome ice core with respect to EDC caused by the lower elevation of the drill site can also not account quantitatively for this difference. A possible change in impurity concentration could potentially add small contributions from in situ production of $\mathrm{CO}_{2}$, which can not be ruled out completely in Antarctic ice cores (Ahn et al., 2012). Note also that at depths below $1200 \mathrm{~m}$ in the EDC and $1100 \mathrm{~m}$ in the Talos Dome ice core, most air is stored in clathrates (Lüthi et al., 2010). For dry extraction methods this could potentially affect the measurement results. However, 


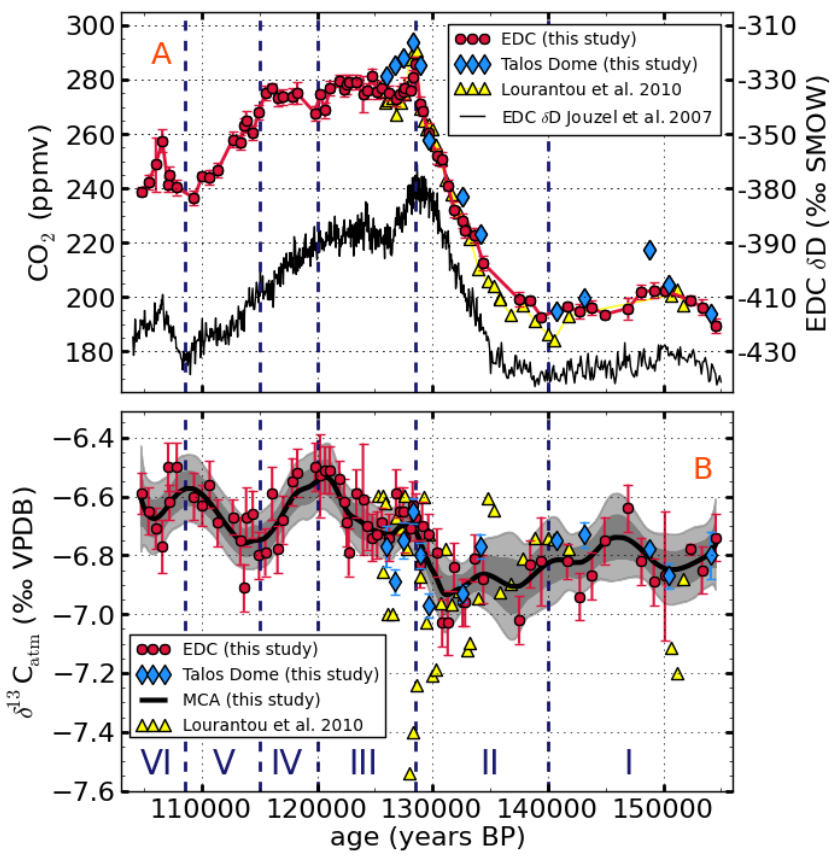

Fig. 1. $\delta^{13} \mathrm{C}_{\text {atm }}$ and $\mathrm{CO}_{2}$ measured in air trapped in ice from Dome $\mathrm{C}$ and Talos Dome, Antarctica over the time interval 155000 105000 yr BP: in (A), $\mathrm{CO}_{2}$ (red circles) measurements on Dome $\mathrm{C}$ (EDC3 age scale) and on the Talos Dome (blue diamonds) ice cores (EDC3 synchronized TALDICE-1a age scale) are shown (this study). Previous data by Lourantou et al. (2010b) are presented with yellow, upward pointing triangles. On a second ordinate, the $\delta D$ values from the EDC ice core (black line) are plotted as proxy for Antarctic temperature evolution (Jouzel et al., 2007). In (B) the associated $\delta^{13} \mathrm{C}_{\mathrm{atm}}$ data for EDC (red circles) and for Talos Dome (blue diamonds) are shown. The error bars represent the one $\sigma$ standard deviation of replicate measurements. Where only one sample was measured the mean reproducibility is given as error estimate. For our EDC and Talos Dome data a Monte Carlo Average (MCA) (solid black line) was calculated as described by Schmitt et al. (2012). The one $\sigma$ standard deviation of the MCA is highlighted by the dark grey shaded area, whereas the light grey band pictures the two $\sigma$ uncertainty. Previously published $\delta^{13} \mathrm{C}_{\text {atm }}$ measurements from the EDC ice core (Lourantou et al., 2010b) are shown in yellow upward pointing triangles. $\mathrm{CO}_{2}, \delta D$ and $\delta^{13} \mathrm{C}_{\mathrm{atm}}$ are subdivided into six time periods ranging from I to VI (see main text for further details).

since we use sublimation with $100 \%$ extraction efficiency, the storage in bubbles or clathrates should have no effect on our analysis. Gas fractionation during the formation of clathrates in the ice, as observed for different gas species, may potentially also result in $\delta^{13} \mathrm{C}$ variations on scales of centimetres as reported for $\mathrm{O}_{2} / \mathrm{N}_{2}$ ratios (Kawamura et al., 2007) and $\mathrm{CO}_{2}$ (Bereiter et al., 2009; Lüthi et al., 2010), i.e. of equal scale as the length of our $\delta^{13} \mathrm{C}_{\mathrm{atm}}$ samples. Similar to the variations in $\mathrm{CO}_{2}$ concentrations observed in $\mathrm{EDC}$ ice, potential $\delta^{13} \mathrm{C}$ variations due to clathrate fractionation may not be completely smoothed out by diffusion in cold EDC ice within the depth interval $200 \mathrm{~m}$ below the bubble clathrate transition zone (BCTZ). On the other hand small-scale $\mathrm{CO}_{2}$ variations disappear quite rapidly below the BCTZ at Talos Dome (Lüthi et al., 2010) and, thus, also a more efficient diffusional equilibration of potential $\delta^{13} \mathrm{C}$ variations is to be expected in this core. We also compared our data with published data for Termination II by Lourantou et al. (2010b), which were also measured on the EDC ice core. A LGM value of $-6.56 \%$ measured by Lourantou et al. (2010a) was about $0.16 \%$ o lower than our sublimation measurements with a mean $\delta^{13} \mathrm{C}$ value of $-6.40 \%$ (Schmitt et al., 2012). For this time interval, this offset between the Schmitt et al. (2012) and the Lourantou et al. (2010a) EDC bubble ice data was systematic and was attributed to any method specific systematic fractionation. In contrast, our comparatively constant $\delta^{13} \mathrm{C}_{\mathrm{atm}}$ level of $-6.8 \pm 0.06 \%$ for the PGM derived on this clathrated ice appears to be in agreement with the PGM level of $-6.8 \pm 0.1 \%$ from Lourantou et al. (2010b) (Fig. 1b) without invoking a systematic offset. However, given the combined scatter of the Lourantou et al. (2010b) and our data for the PGM time interval, an analytical offset on the order of $0.1 \%$ might still be hidden in the measurement error.

\subsection{Gravitational correction}

During the enclosure process in the ice, the air undergoes fractionation due to gravitational settling in the firn column, which is only dependent on the mass difference between ${ }^{12} \mathrm{C}$ and ${ }^{13} \mathrm{C}$. The $\delta^{13} \mathrm{C}_{\mathrm{atm}}$ data are corrected for this gravitational fractionation using the stable isotope ratio of $\mathrm{N}_{2}\left(\delta^{15} \mathrm{~N}\right)$. Since $\mathrm{N}_{2}$ has a much longer atmospheric lifetime than the time intervals considered here, $\delta^{15} \mathrm{~N}$ changes only reflect the change in gravitational fractionation in the firn column (Dreyfus, 2008). Note that due to thermo-diffusion effects in the firn column $\delta^{15} \mathrm{~N}$ can also be affected by temperature changes, which however is of negligible importance for the EDC and Talos Dome sites, where temperature changes are reported to be slow (Jouzel et al.,2007; Stenni et al., 2011). Since $\delta^{15} \mathrm{~N}$ data are not available for all EDC depth intervals, we used a linear regression between the measured water isotopes of the ice and measured $\delta^{15} \mathrm{~N}$. For the EDC ice core the correlation coefficient between $\delta D$ and $\delta^{15} \mathrm{~N}$ is $R^{2}=0.88$. The correction for gravitational fractionation in $\delta^{13} \mathrm{C}_{\mathrm{atm}}$ on ice from EDC is between -0.35 and $-0.55 \%$, while Talos Dome samples are corrected by -0.35 to $-0.42 \%$ (Landais et al., 2013). The error introduced by the $\delta^{15} \mathrm{~N}$ measurement itself is negligible because $\delta^{15} \mathrm{~N}$ can be measured with precisions of $0.01 \%$, which is much smaller than the reproducibility of $\delta^{13} \mathrm{C}_{\mathrm{atm}}$. However, the linear regression between $\delta D$ and $\delta^{15} \mathrm{~N}$ introduces an error between 0.04 and $0.05 \%$ at interglacial and glacial climate conditions, respectively. This additional uncertainty is affecting the overall values of our data systematically, thus the absolute accuracy of the complete data set. 


\subsection{Monte Carlo cubic spline average}

Following the mathematical procedure as described in detail in Schmitt et al. (2012), a Monte Carlo cubic spline Average (MCA) was calculated to extract the robust $\delta^{13} \mathrm{C}_{\text {atm }}$ trend information. We calculated 4000 cubic splines for the measured data. The cut-off frequency (Enting, 1987) of the individual splines was chosen to roughly eliminate periods below 375 yr. Choosing a different number would result in MCAs with more or less wiggles. The cut-off of $375 \mathrm{yr}$ accounts for the magnitude of the signal damping in the EDC ice core at that time (described in detail in Schmitt et al., 2012). Due to the gas enclosure process, shorter periods than $375 \mathrm{yr}$ cannot be resolved in measurements. Thus, with choosing $375 \mathrm{yr}$ as cut-off, we retain the maximum temporal resolution possible. Note however that the true atmospheric evolution is not represented by the spline itself; it provides just a guide to the eye. The true centennial atmospheric evolution follows a temporal evolution that stays within the error range of the MCA. Furthermore, a bootstrapping method was performed to detect possible outliers in the data set as described in Schmitt et al. (2012). However, based on our bootstrapping outlier criterion (Schmitt et al., 2012), not a single point of our sublimation measurements was incompatible with the long-term trend, underlining the high quality of our $\delta^{13} \mathrm{C}_{\mathrm{atm}}$ data obtained with the sublimation method.

\section{Results}

In Fig. 1a we present our new $\mathrm{CO}_{2}$ record between 155000 and $105000 \mathrm{yr}$ BP from the EDC and Talos Dome ice cores. The stable carbon isotopic composition $\delta^{13} \mathrm{C}_{\mathrm{atm}}$ is shown in Fig. 1b. Both the $\mathrm{CO}_{2}$ concentration and $\delta^{13} \mathrm{C}_{\mathrm{atm}}$ are compared to the EDC data of Lourantou et al. (2010b). The $\delta D$ record (a proxy for local temperature) from the EDC ice core (Jouzel et al., 2007) is shown on a second ordinate in Fig. 1a to illustrate leads and lags between atmospheric $\mathrm{CO}_{2}$ and temperature. Note, however, that the uncertainty in the ice age/gas age difference ( $\Delta$ age) must be taken into consideration: for instance, $\Delta$ age is 4200 and $2000 \mathrm{yr}$ (Parrenin et al., 2007) at the PGM and the MIS5.5, respectively, and relative errors in $\Delta$ age are about $20 \%$ (Buiron et al., 2011). The data can be divided into six time periods of distinct characteristics for $\mathrm{CO}_{2}, \delta^{13} \mathrm{C}_{\mathrm{atm}}$ and $\delta D$. The first interval I (the end of the penultimate glacial), from 155000 to $140000 \mathrm{yr} \mathrm{BP}$ is characterised by fairly constant atmospheric values around $195 \mathrm{ppm} \mathrm{CO} 2$ and $-6.8 \%$ ofor $\delta^{13} \mathrm{C}_{\mathrm{atm}}$, which is about $0.4 \%$ 。 lower than during the LGM (Schmitt et al., 2012) (Fig. 2). At $140000 \mathrm{yr} \mathrm{BP}$ our new $\mathrm{CO}_{2}$ and the EDC $\delta D$ data show minima of $193 \mathrm{ppm}$ and $-440 \%$, respectively. Interval II (the penultimate glacial/interglacial transition from 140000 to $128500 \mathrm{yr} \mathrm{BP}$ ) is characterised by rises in $\delta D$ and $\mathrm{CO}_{2}$. Starting at the $\mathrm{PGM}, \mathrm{CO}_{2}$ gradually increases to peak values of $286 \mathrm{ppm}$ at $128500 \mathrm{yr}$ BP. The Talos Dome data show an
8 ppm higher maximum than EDC at that time. The maximum in $\mathrm{CO}_{2}$ at the onset of MIS5.5 lags behind the $\delta D$ maximum by 500 to $1500 \mathrm{yr}$, which is on the same order of magnitude than the uncertainty of about $400 \mathrm{yr}$ in $\Delta$ age at $128500 \mathrm{yr}$ BP (Parrenin et al., 2007, Buiron et al., 2011). No significant difference in the more slowly changing $\delta^{13} \mathrm{C}_{\mathrm{atm}}$ evolution is seen between the two ice cores. According to our new data a maximum atmospheric $\delta^{13} \mathrm{C}_{\text {atm }}$ decrease of about $0.2 \%$, to $-7.0 \%$ is observed between the PGM and $131000 \mathrm{yr} \mathrm{BP}$. Note that the temporal resolution is rather low in this time interval, which compromises the robustness of the magnitude of the $\delta^{13} \mathrm{C}_{\mathrm{atm}}$ drop. At $131000 \mathrm{yr} \mathrm{BP} \delta^{13} \mathrm{C}_{\mathrm{atm}}$ starts to rise from -7.0 to $-6.7 \%$ and continues to do so until $128500 \mathrm{yr}$ BP. To illustrate differences in the $\mathrm{CO}_{2}$ records across Termination II, data from Lourantou et al. (2010b), Petit et al. (1999) and from this study are plotted in Fig. 3. Before $128500 \mathrm{yr} \mathrm{BP}$ our new $\mathrm{CO}_{2}$ data agree well with the data published in Petit et al. (1999), Fischer et al. (1999), and Lourantou et al. (2010b). However, between 128000 to $126000 \mathrm{yr}$ BP our data suggest very constant $\mathrm{CO}_{2}$ concentrations of about $275 \mathrm{ppm}$, whereas Petit et al. (1999) and Lourantou et al. (2010b) report $\mathrm{CO}_{2}$ fluctuations between 265 and $280 \mathrm{ppm}$. Small overall offsets between $\mathrm{CO}_{2}$ records from clathrate ice of the same ice cores along the same time intervals are most probably due to the specific air extraction techniques used in different studies. Gas extraction based on mechanical destruction of the ice matrix as used by Petit et al. (1999) and Lourantou et al. (2010b) suffers from incomplete and incongruent extraction as release of $\mathrm{CO}_{2}$ from decomposing air clathrates is slower than for other gases such as $\mathrm{O}_{2}$ and $\mathrm{N}_{2}$ (Lüthi et al., 2010). Moreover, larger clathrates may be depleted in $\mathrm{CO}_{2}$ compared to smaller clathrates but are preferentially released during dry extraction (Bereiter et al., 2012). In contrast, sublimation of the ice sample, as used in our study, ensures a $100 \%$ effective extraction of the air and, therefore, an unbiased $\mathrm{CO}_{2}$ reconstruction. In the case of the $\mathrm{CO}_{2}$ mismatch of $8 \mathrm{ppm}$ around $128000 \mathrm{yr} \mathrm{BP}$ of our measurements derived for Talos Dome and EDC (Fig. 3), both records were measured with the sublimation technique. Hence, other potential processes have to be considered to explain this difference: (i) dating inconsistencies between the records; (ii) in situ production of $\mathrm{CO}_{2}$; (iii) differences in gravitational enrichment; and (iv) a different damping of fast $\mathrm{CO}_{2}$ changes connected to the different gas enclosure characteristics. Schüpbach et al. (2011) improved the dating of the deep Talos Dome ice core section using a high-resolution methane record between 112000 to $55000 \mathrm{yr}$ BP. Yet, no improvements to the TALDICE-1 age scale (Buiron et al., 2011) were achieved for times older than $112000 \mathrm{yr}$ BP. Applying an age scale compression of the TALDICE-1 dating (process i) between 129000 and $126000 \mathrm{yr} \mathrm{BP}$, the broad shape of the early $\mathrm{CO}_{2}$ peak from the Talos Dome matches the timing of the peak reconstructed from the EDC ice core, but can not explain the higher $\mathrm{CO}_{2}$ concentrations. In situ production of $\mathrm{CO}_{2}$ (process ii) in the Talos Dome ice core is unlikely to 

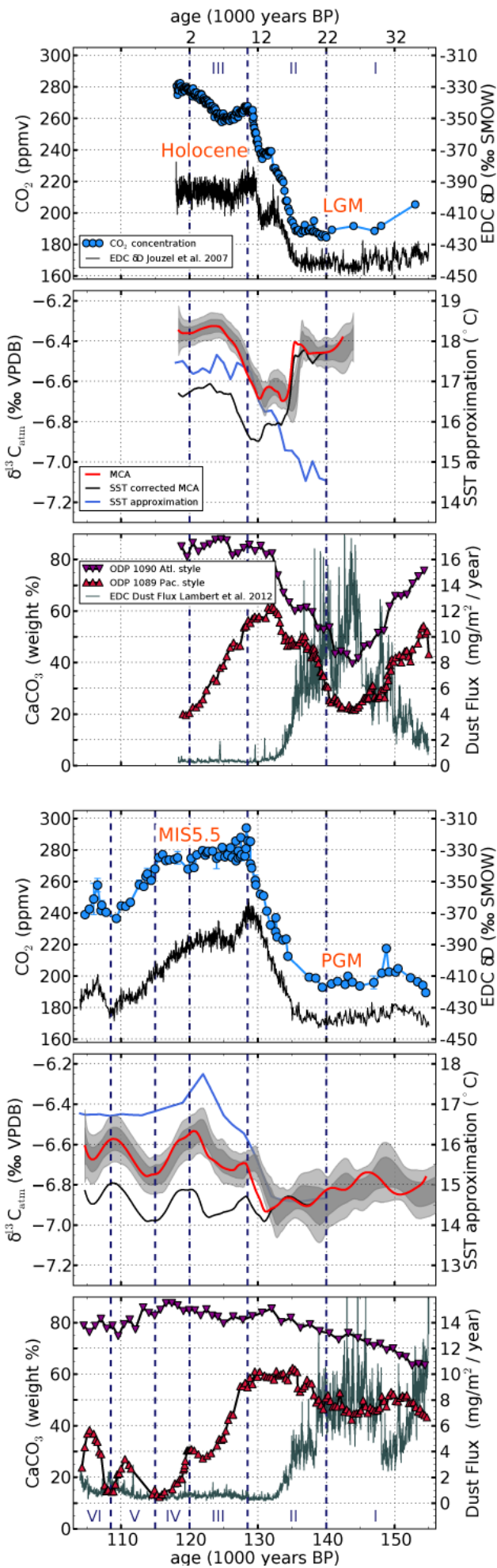

Fig. 2. Comparison of carbon cycle changes around Termination I and II: the top panels show from top to bottom: $\mathrm{CO}_{2}$ (blue circles, Monnin et al., 2001) and $\delta D$ (black line, Jouzel et al., 2007), the $\delta^{13} \mathrm{C}_{\text {atm }}$ MCA (red line, Schmitt et al., 2012) as well as a SST-corrected version (black line) according to a global SST reconstruction, which is based on the sea-ice-free surface ocean only (light blue line) (Köhler and Fischer, 2006), $\mathrm{CaCO}_{3}$ weight percent content of sediment cores ODP1089 (red upward pointing triangles) and ODP1090 (magenta downward pointing triangles) (Hodell et al., 2001) as well as the dust flux reconstructed from the EDC ice core (grey line) (Lambert et al., 2012) for the last 24000 yr. Ice core data are given on the EDC3/TALDICE-1a age scale, while marine $\mathrm{CaCO}_{3}$ reconstructions are given on their individual age scales. In the lower panels, the same species are plotted for the time between $155000-105000 \mathrm{yr} \mathrm{BP} . \mathrm{CO}_{2}$ (blue circles), the $\delta^{13} \mathrm{C}_{\mathrm{atm}} \mathrm{MCA}$ (red line), and SST-corrected $\delta^{13} \mathrm{C}_{\mathrm{atm}} \mathrm{MCA}$ (black line) are from this study. Uncertainty ranges for the ${ }^{13} \mathrm{C}_{\mathrm{atm}}$ MCAs represent the one $\sigma$ and two $\sigma$ confidence intervals (compare Fig. 1 for further explanation). Plotted data are aligned for coinciding $\mathrm{CO}_{2}$ maxima at the end of Termination I and II. The LGM, here defined as $22000 \mathrm{yr}$ BP (Clark et al., 2009), is aligned to the PGM time slice, here defined as the temperature minimum at $140000 \mathrm{yr}$ BP. Data are subdivided into the same time periods as in Fig. 1. 


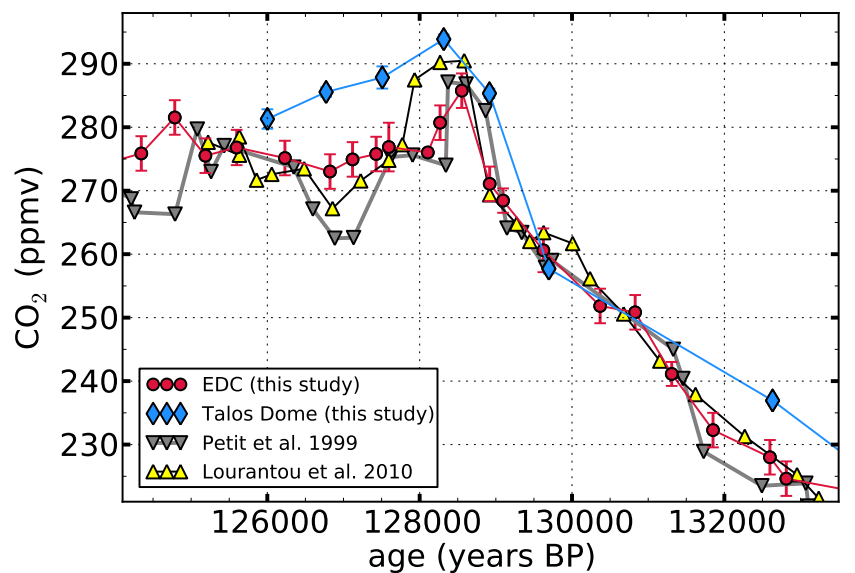

Fig. 3. $\mathrm{CO}_{2}$ as in Fig. 1 but zoomed to 132500 to $124000 \mathrm{yr} \mathrm{BP}$ : $\mathrm{CO}_{2}$ (red circles) measurements on EDC (EDC3 age scale) and on the Talos Dome (blue diamonds) ice cores (TALDICE-1a age scale) from this study are shown next to $\mathrm{CO}_{2}$ data previously measured by Petit et al. (1999) (grey downward pointing triangles) on the Vostok ice core and the reconstructions from Lourantou et al. (2010b) (yellow, upward pointing triangles) on EDC.

account for the offset since the $\delta^{13} \mathrm{C}_{\mathrm{atm}}$ data from both ice cores agree within their uncertainties for that time interval. A strong depletion in the measured $\delta^{13} \mathrm{C}$ would be expected (Francey et al., 1997) from $\mathrm{CO}_{2}$ in situ production due to microbial activity. Only if the $\mathrm{CO}_{2}$ in situ production results from inorganic, acid-carbonate chemical reactions the effect on $\delta^{13} \mathrm{C}$ could be smaller and may remain undetected in our $\delta^{13} \mathrm{C}_{\mathrm{atm}}$ data. However, so far there is no indication of such carbonate reactions in the Talos Dome ice core. Compared to other ice cores, Talos Dome shows low dust concentrations (Delmonte et al., 2010; Schüpbach et al., 2013). Furthermore, Talos Dome replicates of same depth intervals show the best quality in $\delta^{13} \mathrm{C}$, i.e. error bars are smaller than for example for the scattered EDML data, where it is known that a very small contribution of in situ production of $\mathrm{CO}_{2}$ occurs (Schneider, 2011). Hence, we do not have a hint for disturbed $\delta^{13} \mathrm{C}$ and $\mathrm{CO}_{2}$ data from Talos Dome, however, we cannot completely rule out an in situ effect even smaller than for EDML. Also, differences in gravitational correction between the ice cores (process iii) cannot sufficiently explain the observed offset in $\mathrm{CO}_{2}$ as the offset even increases by $1 \mathrm{ppm}$ when correcting both ice cores for gravitational settling and thus enrichment of $\mathrm{CO}_{2}$. Thus, a damping of relative short-lived $\mathrm{CO}_{2}$ changes (process iv), which is different in the two ice cores is likely to account for the offset. Accumulation rates are higher in the Talos Dome (Stenni et al., 2011) than the EDC (Parrenin et al., 2007) ice core. Therefore fast fluctuations in atmospheric $\mathrm{CO}_{2}$ are less damped in the Talos Dome than in the EDC ice core. Using recent (interglacial) bubble enclosure characteristics for EDC and Talos Dome (Joos and Spahni, 2008) a $\mathrm{CO}_{2}$ variation of $20 \mathrm{ppm}$ with a wavelength of $1000 \mathrm{yr}$ (similar to the $\mathrm{CO}_{2}$ change observed in the Talos Dome ice core at the beginning of MIS5.5) would be damped to $13 \mathrm{ppm}$ in the EDC ice core in line with our observations. Note that including more $\mathrm{CO}_{2}$ measurements along the respective time interval from other ice cores like Dome Fuji could help to assess the early $\mathrm{CO}_{2}$ peak in MIS5.5. However, the existing data sets measured by Kawamura et al. (2007) do not help as wet and dry extraction data neither completely agree with each other nor with other data by e.g. Petit et al. (1999). Especially for MIS5.5 the wet extraction $\mathrm{CO}_{2}$ data is significantly higher than the dry extracted $\mathrm{CO}_{2}$ data, which resembles the Petit et al. (1999) value more closely. Accordingly, the wet extraction data do not help to assess the early $\mathrm{CO}_{2}$ peak in MIS5.5. Unfortunately, there exist no dry extraction $\mathrm{CO}_{2}$ data from Dome Fuji for the onset of MIS5.5 so far. Our preferred interpretation at the moment is that there may exist an anomalous stretching of the gas ice scale of the Talos Dome ice core at that point. This is also supported by a few $\mathrm{CH}_{4}$ measurements available at that point (Schilt et al., 2010), which also show a wider early $\mathrm{CH}_{4}$ peak at the onset of MIS5.5 compared to other ice core records. However, a final answer can only be given after high-resolution $\mathrm{CH}_{4}$ and other records become available from this time interval. In summary, a combination of both an age scale problem and different damping characteristics of the analysed ice cores can explain the $\mathrm{CO}_{2}$ mismatch during this time interval. At the onset of time interval III, $128500 \mathrm{yr} \mathrm{BP}, \mathrm{CO}_{2}$ concentrations as well as EDC $\delta D$ slightly decline to $276 \mathrm{ppm}$ and $-387 \%$, respectively. From $126000 \mathrm{yr} \mathrm{BP}$ onwards, $\mathrm{CO}_{2}$ concentrations as well as $\delta D$ remain constant at about $276 \mathrm{ppm}$ and $-387 \%$, respectively, until the end of interval III at $120000 \mathrm{yr} \mathrm{BP}$. A further increase in $\delta^{13} \mathrm{C}_{\mathrm{atm}}$ by about $0.2 \%$, to $-6.55 \%$, is found within interval III from about 124000 to $120000 \mathrm{yr}$ BP. At a closer look, the boundary between interval III and IV at $120000 \mathrm{yr}$ marks a millennial scale excursion in atmospheric $\mathrm{CO}_{2}$. Interval IV starts at $120000 \mathrm{yr} \mathrm{BP}$ and lasts until $115000 \mathrm{yr} \mathrm{BP}$. This interval is characterised by rather constant $\mathrm{CO}_{2}$ concentrations around $276 \mathrm{ppm}$, whereas EDC temperature decreases by $3 \mathrm{~K}$ (Jouzel et al., 2007) as derived from the decline of $\delta D$ from -390 to $-408 \%$ o. At the same time, atmospheric $\delta^{13} \mathrm{C}_{\text {atm }}$ drops from -6.55 by about -0.2 to $-6.75 \%$. Finally at $115000 \mathrm{yr} \mathrm{BP}$, the beginning of interval $\mathrm{V}, \mathrm{CO}_{2}$ drops by $40 \mathrm{ppm}$ in $10000 \mathrm{yr}$ to $240 \mathrm{ppm}$. During the $\mathrm{CO}_{2}$ decline starting at $115000 \mathrm{yr} \mathrm{BP}, \delta^{13} \mathrm{C}_{\mathrm{atm}}$ increases again to $-6.55 \%$. Note that the Antarctic temperature decrease during interval IV leads the $\mathrm{CO}_{2}$ decrease in interval $\mathrm{V}$ by up to $5000 \mathrm{yr}$ on the EDC3 age scale as previously observed in the Vostok ice core (Fischer et al., 1999; Cuffey and Vimeux, 2001). This lag is significantly larger than the $\Delta$ age uncertainty at this time. Between 108500 to $105000 \mathrm{yr} \mathrm{BP}$ (interval VI) our new $\mathrm{CO}_{2}$ and $\delta^{13} \mathrm{C}_{\mathrm{atm}}$ data cover the Antarctic Isotope Maxima (AIM) event number 24 (Capron et al., 2010). EDC temperature rises by $4 \mathrm{~K}$, according to an increase of $\delta D$ from -434 to $-409 \%$. At the same time, our 
$\mathrm{CO}_{2}$ data show a clear peak of $20 \mathrm{ppm}$, which is reproduced in the EDML record (Bereiter et al., 2012).

\section{Discussion}

\subsection{Scrutinizing rapid $\delta^{13} \mathrm{C}_{\mathrm{atm}}$ variations previously found during Termination II}

In Fig. 1 our new $\delta^{13} \mathrm{C}_{\mathrm{atm}}$ and $\mathrm{CO}_{2}$ data are compared to published measurements from the same EDC ice core covering Termination II (Lourantou et al., 2010b). $\mathrm{CO}_{2}$ measurements of both studies basically show the same picture: fairly constant $\mathrm{CO}_{2}$ concentrations during the PGM, which strongly rose during the Termination and ended with $\mathrm{CO}_{2}$ peak concentrations of $290 \mathrm{ppm}$ at $128500 \mathrm{yr}$ BP. However, $\delta^{13} \mathrm{C}_{\mathrm{atm}}$ measurements from Lourantou et al. (2010b) show deviations of -0.8 to $+0.2 \%$ relative to our $\delta^{13} \mathrm{C}_{\text {atm }}$ record. The most striking difference to the MCA is observed at $128000 \mathrm{yr}$ BP. Lourantou et al. (2010b) found a sharp negative excursion in $\delta^{13} \mathrm{C}_{\mathrm{atm}}$ of about $-0.66 \%$ in $1000 \mathrm{yr}$, which is in concert with the early $\mathrm{CO}_{2}$ peak at $128500 \mathrm{yr} \mathrm{BP}$. This excursion in their data set is represented by three data points at 128500,128200 and $127900 \mathrm{yr} \mathrm{BP}$ with $\delta^{13} \mathrm{C}_{\text {atm }}$ values of $-7.25,-7.4$ and $-7.55 \%$, and $\mathrm{CO}_{2}$ concentrations of 290,290 and $287 \mathrm{ppm}$, respectively. At $127700 \mathrm{yr}$ BP the stable carbon isotopic signal rises again to $-6.8 \%$ in $\delta^{13} \mathrm{C}_{\mathrm{atm}}$ and $277 \mathrm{ppm}$ in $\mathrm{CO}_{2}$ within only $200 \mathrm{yr}$. While we also find the pronounced $\mathrm{CO}_{2}$ maximum at the onset of MIS5.5, the strong drop in $\delta^{13} \mathrm{C}_{\mathrm{atm}}$ is not visible in our data. We performed high-resolution sampling on both, the EDC and Talos Dome ice cores, around the time interval of this large $\delta^{13} \mathrm{C}_{\mathrm{atm}}$ excursion, but no trace of such a drop could be found (Fig. 1b). Such a fast change in $\delta^{13} \mathrm{C}_{\mathrm{atm}}$ and the connected changes in the carbon cycle have not been found in any other pre-industrial time interval previously studied for $\delta^{13} \mathrm{C}_{\mathrm{atm}}$. We discuss in the following whether such an anomaly in $\delta^{13} \mathrm{C}_{\mathrm{atm}}$ can potentially be explained by natural carbon cycle fluctuations. To put such high anomalies into perspective to variations potentially observed in the carbon cycle it is useful to consider the human perturbation of the carbon cycle of the recent past. The unprecedented anthropogenic $\mathrm{CO}_{2}$ emissions from fossil fuel burning and land use, which amount to more than $500 \mathrm{GtC}$ in the last $250 \mathrm{yr}$ (Boden et al., 2011; Houghton, 2010), has led to a rise of more than $100 \mathrm{ppm}$ in atmospheric $\mathrm{CO}_{2}$ (Etheridge et al., 1996; Keeling et al., 2009) and a $\delta^{13} \mathrm{C}_{\mathrm{atm}}$ decrease of $-1.9 \%$ from pre-industrial conditions of -6.3 to $-8.2 \%$ in $2010 \mathrm{AD}$ (Francey et al., 1999; Keeling et al., 2010). Thus, a $0.7 \%$ drop in $200 \mathrm{yr}$ during Termination II accompanied by a $\mathrm{CO}_{2}$ increase of not more than $20 \mathrm{ppm}$ represents an extraordinary perturbation. Moreover, the true atmospheric signal in $\mathrm{CO}_{2}$ and $\delta^{13} \mathrm{C}_{\mathrm{atm}}$ was even larger than the signal recorded in the ice core. The amplitude of $\mathrm{C}_{2}$ peak recorded in the ice core depends on the age distribution during gas enclosure and the rate of $\mathrm{CO}_{2}$ emissions. Accumulation rates in Antarctica during MIS5.5 were higher than at present day (Parrenin et al., 2007), therefore the gas age distribution during gas enclosure was narrower at that time than for recent times. For the Holocene, the mean width of this age distribution was calculated to be about $200 \mathrm{yr}$ (Joos and Spahni, 2008). In the EDC ice core this leads to a damping to about $40 \%$ of the true atmospheric $\delta^{13} \mathrm{C}_{\mathrm{atm}}$ variations for periodicities of $600 \mathrm{yr}$ (Köhler et al., 2010). Thus, neglecting any effect of uncertain emission rates we estimate that the true atmospheric signal underlying the data of Lourantou et al. (2010b) around $128000 \mathrm{yr}$ BP would have been as much as $-1.6 \%$. If such a negative anomaly in $\delta^{13} \mathrm{C}_{\mathrm{atm}}$ represents a true climatic signal, one has to assume drastic environmental changes such as a sea level change during Termination II leading to a rapid sea level rise of $20-40 \mathrm{~m}$ within $1000 \mathrm{yr}$ and a release of carbon formerly stored on coastal areas (Siddall et al., 2006; Kopp et al., 2009). A similar flooding hypothesis has recently been proposed to explain the rapid jump in $\mathrm{CO}_{2}$ around $14600 \mathrm{yr} \mathrm{BP}$ during meltwater pulse 1A (Köhler et al., 2011). Such a scenario would release terrestrial carbon with light ${ }^{13} \mathrm{C}$ values in line with a large negative anomaly in $\delta^{13} \mathrm{C}_{\mathrm{atm}}$. However, a box modelling approach (Köhler et al., 2011), shows that a true atmospheric anomaly in $\delta^{13} \mathrm{C}_{\mathrm{atm}}$ of $-0.87,-1.26$ or $-1.62 \%$, caused by the injection of 200,300 or $400 \mathrm{GtC}$ within $100 \mathrm{yr}$ would also lead to an atmospheric $\mathrm{CO}_{2}$ rise of 47,73 and $99 \mathrm{ppm}$, respectively, which is not seen in our record. The recovery in $\delta^{13} \mathrm{C}_{\mathrm{atm}}$ between 127900 and $127700 \mathrm{yr}$ BP from -7.55 to $-6.8 \%$, i.e. $0.75 \%$ in $200 \mathrm{yr}$, implies even higher rates of change, and is even more difficult to explain on the basis of natural carbon cycle fluctuations. To explain the dramatic excursion in the Lourantou et al. (2010b) data, we must rather consider (i) unidentified analytical problems (e.g. contamination) or (ii) fractionation due to an incomplete gas release during the dry extraction. In summary, we conclude that rapid variations in $\delta^{13} \mathrm{C}_{\mathrm{atm}}$ within a few centuries appear to be unlikely to have occurred at any time in our record in line with the rather slow evolution of $\mathrm{CO}_{2}$ concentration in the same time interval.

\subsection{Comparison of sequence of events around Termination II and Termination I}

From our new $\delta^{13} \mathrm{C}_{\text {atm }}$ data we calculate a Monte Carlo average (MCA) using the method described in Schmitt et al. (2012) to illustrate the significant millennial changes in $\delta^{13} \mathrm{C}_{\mathrm{atm}}$. The MCAs for the last $24000 \mathrm{yr}$ and for 155000 $105000 \mathrm{yr}$ BP are shown in Fig. 2. To compare Termination II with Termination I, the $x$ axes are aligned, such that the first $\mathrm{CO}_{2}$ maxima at the end of Termination I and II match. Thus, the LGM time slice, corresponding to $22000 \mathrm{yr}$ BP (Clark et al., 2009), coincides with the PGM at $140000 \mathrm{yr} \mathrm{BP}$. Also illustrated in the same figure is the atmospheric $\mathrm{CO}_{2}$ and EDC $\delta D$ evolution (Jouzel et al., 2007) within the same time frames. Within the uncertainty, $\delta^{13} \mathrm{C}_{\mathrm{atm}}$ 
is roughly constant around $-6.8 \%$ during the PGM between 155000 and $140000 \mathrm{yr} \mathrm{BP}$. This is consistent with the carbon cycle being in dynamic equilibrium during both the LGM (Schmitt et al., 2012) and the PGM, however the average PGM $\delta^{13} \mathrm{C}_{\mathrm{atm}}$ value is $0.4 \%$ o lower than for the LGM (see Sect. 4.4 for further discussion of this difference). The $\delta^{13} \mathrm{C}_{\mathrm{atm}}$ evolution is characterised by a sharp synchronous decline at the start of the $\mathrm{CO}_{2}$ rise in Termination I (Fig. 2). From 17000 to $16000 \mathrm{yrBP}$ a strong $\delta^{13} \mathrm{C}_{\mathrm{atm}}$ decrease to $-6.7 \%$ is observed, which is accompanied by rising $\mathrm{CO}_{2}$ concentrations, warmer Antarctic temperatures and a strong drop in aeolian dust deposition in the Southern Ocean region. Note that dust fluxes are higher during the LGM than at the onset of the $\mathrm{CO}_{2}$ rise (Fig. 2). During Termination II the stable carbon isotope signature decreases by about $0.2 \%$ from about 136000 to $130000 \mathrm{yr} \mathrm{BP}$. As temporal resolution as well as precision of the $\delta^{13} \mathrm{C}_{\mathrm{atm}}$ data are comparably low in that time interval it is hard to tell when exactly $\delta^{13} \mathrm{C}_{\mathrm{atm}}$ starts to drop and how large the drop is. Note that also the MCA spline, which takes the single point uncertainty and the density of points into account, shows a $\delta^{13} \mathrm{C}_{\mathrm{atm}}$ decline, although with a large uncertainty. However, we can say that the major increase in $\mathrm{CO}_{2}$ (and $\delta D$ ) starts at $136000 \mathrm{yr} \mathrm{BP}$, while the first strong decrease in aeolian dust deposition (Fig. 2) occurs already at $138000 \mathrm{yr}$ BP (Lambert et al., 2012). Also it becomes clear that the overall magnitudes of the $\delta^{13} \mathrm{C}_{\mathrm{atm}}$ decline at the start of Termination I and II are slightly different: after the LGM $\delta^{13} \mathrm{C}_{\mathrm{atm}}$ drops by about $0.3 \%$, whereas along Termination II a maximum decline of $0.2 \%$ is found. Interestingly, the terminations are also characterised by generally enhanced preservation of $\mathrm{CaCO}_{3}$ as reconstructed from the sediment cores ODP1089 and ODP1090, drilled in the Cape Basin, located in the Atlantic sector of the Southern Ocean (Hodell et al., 2001) (Fig. 2). ODP1089 was drilled at $4600 \mathrm{~m}$ depth, recording the Pacific Basin style $\mathrm{CaCO}_{3}$ development (Farell and Prell, 1989, Hodell et al., 2011). This region is exclusively flushed with low alkalinity water originating from Circumpolar Deep Water (Hodell et al., 2001, 2003; Rickaby et al., 2010). The Atlantic Basin style is represented by ODP 1090 drilled at a depth of $3700 \mathrm{~m}$, where northern sourced waters of high alkalinity control the preservation history (Hodell et al., 2001, 2003; Rickaby et al., 2010). Hence, ODP1090 is mainly influenced by changes in ocean circulation strength and stratification of North Atlantic Deep Water (NADW), whereas preservation and dissolution events characteristic for the deep Indo-Pacific Ocean are recorded in ODP1089. The $\mathrm{CaCO}_{3}$ preservation histories of ODP1089 and ODP1090 are also consistent with carbonate ion reconstructions from Broecker et al. (1999) and Barker and Elderfield (2002). Nevertheless, trends are only qualitatively covered, as changes in weight percent do not linearly correlate with the sedimentation rate. According to Francois et al. (1997), Spero and Lea (2002), Barker et al. (2004), Anderson et al. (2009), Tschumi et al. (2011) and Schmitt et al. (2012), a strengthening of the Southern Ocean mixing, transporting isotopically light carbon from the deep ocean to the surface, was most likely responsible for the decreasing $\delta^{13} \mathrm{C}_{\mathrm{atm}}$ at the start of the deglaciation in accordance with the $\mathrm{CO}_{2}$ and $\mathrm{CaCO}_{3}$ preservation increases. Most likely, this carbon had been previously accumulated in the deep ocean due to decreased ventilation of Antarctic Bottom Waters during glacial times. Also a decrease in iron fertilisation of the surface productivity in the Southern Ocean synchronous to the decline in aeolian dust deposition at the onset of the termination may have contributed to the early $\delta^{13} \mathrm{C}_{\mathrm{atm}}$ decrease, however model experiments show that the change in the biological pump due to increasing iron limitation at that time can only explain about half of the $\delta^{13} \mathrm{C}_{\mathrm{atm}}$ decline (Köhler et al., 2005, 2010) observed in our $\delta^{13} \mathrm{C}_{\mathrm{atm}}$ record during Termination I. Note also in Fig. 2 that $\mathrm{CO}_{2}$ increases significantly only after dust fluxes have already declined from the glacial maximum values to about $4-6 \mathrm{mg} \mathrm{m}^{-2} \mathrm{yr}^{-1}$ at the start of the termination. The $\mathrm{CaCO}_{3}$ preservation histories of the Atlantic and the Pacific Oceans show opposing behaviour during interglacials and the glacial inception but the same trend during glacials and the deglaciations. Increasing carbonate ion concentration in the deep ocean due to ocean reorganization within a glacial termination may have triggered a deepening of the carbonate compensation depth by about $700 \mathrm{~m}$ (Farrel and Prell, 1989; Broecker et al., 1993), which allows for enhanced $\mathrm{CaCO}_{3}$ preservation in the Atlantic and the Pacific Oceans. A strengthening of deep ocean ventilation during the termination is also supported by deep sea $\delta^{13} \mathrm{C}$ reconstructions of benthic sediment cores (Oliver et al., 2010). Those show increasing deep ocean $\delta^{13} \mathrm{C}$ values throughout the LGM and Termination I, indicating a decrease of the $\delta^{13} \mathrm{C}$ surface to deep ocean gradient (Hodell et al., 2003). While an intensified deep ocean circulation at the start of the deglaciation helps to explain the rising $\mathrm{CaCO}_{3}$ preservation during the terminations, it falls short to explain the fact that preservation increased already $6000 \mathrm{yr}$ before the deglaciation starts. In fact the preservation records (Atlantic and Pacific) are already half way up from their minimum values when the deglaciation starts, pointing to internal processes of the alkalinity budget of the ocean rather than circulation to be responsible for this long-term trend in the preservation history. Note also that the preservation state in the deep ocean was already on a higher level during the PGM than for the LGM, while at the end of Termination II the magnitude of preservation was the same as after Termination I. Additionally, deep ocean $\delta^{13} \mathrm{C}_{\text {DIC }}$ (Oliver et al., 2010) started to rise at least $10000 \mathrm{yr}$ before the PGM, while $\delta^{13} \mathrm{C}_{\mathrm{DIC}}$ in the deep ocean decreased for $10000 \mathrm{yr}$ before the LGM. As shown by transient simulations (Menviel et al., 2012) over the past $130000 \mathrm{yr}$ with a 3-D dynamic ocean model, a multitude of physical and biogeochemical processes influences the spatio-temporal evolution of carbonate preservation, $\delta^{13} \mathrm{C}$ of dissolved inorganic carbon, atmospheric $\mathrm{CO}_{2}, \delta^{13} \mathrm{C}_{\mathrm{atm}}$, and other proxies on millennial and even longer timescales. This is a consequence of 
ocean-sediment interactions and the $\sim 100000 \mathrm{yr}$ timescales associated with the weathering-burial cycle of organic carbon, and calcium carbonate. A fully consistent interpretation of the proxy records over Termination I and II would thus require knowledge of the previous evolution of the Earth System. The major $\delta^{13} \mathrm{C}_{\mathrm{atm}}$ increases in Fig. 2 starting at around 130000 and $12000 \mathrm{yr} \mathrm{BP}$, respectively, can be largely explained by the regrowth of the terrestrial biosphere (Köhler et al., 2005; Köhler and Fischer, 2006; Elsig et al., 2009; Kleinen et al., 2010; Menviel and Joos, 2011) as well as warming SST, where a SST change of $+1 \mathrm{~K}$ induces a $\delta^{13} \mathrm{C}_{\mathrm{atm}}$ fractionation by about $+0.1 \%$ (Zhang et al., 1995). The $\delta^{13} \mathrm{C}_{\mathrm{atm}}$ signal induced from terrestrial carbon build-up is a mixture of a signal composed of $\mathrm{C} 4$ $\left(\delta^{13} \mathrm{C} \sim-10\right.$ to $\left.-14 \% \circ\right)$ and $\mathrm{C} 3\left(\delta^{13} \mathrm{C} \sim-22\right.$ to $\left.-30 \%\right)$ plant type origin (O'Leary, 1981, Ehleringer et al., 1993). As $\mathrm{CO}_{2}$ and temperature increase during glacial terminations, many terrestrial ecosystems store more carbon on land. Additionally, large areas once covered by ice sheets transform to boreal forests and peat lands with high carbon stocks. This net gain in terrestrial carbon is assumed to be partially reduced by carbon release due to shrinking permafrost extent (Zimov et al., 2009). The $\mathrm{CO}_{2}$ evolution at the end of the terminations is similar in that the maximum values are reached already at the very beginning of the interglacial. We attribute the early $\mathrm{CO}_{2}$ maximum mainly to the opposing effects of the ongoing process of carbonate compensation in response to the net glacial/interglacial transfer of carbon from the ocean/atmosphere system to the terrestrial biosphere, as well as the continuing regrowth of the terrestrial biosphere during the early interglacial (Fischer et al., 1999, Indermühle et al., 1999). Note however that $\mathrm{CO}_{2}$ variations result from a subtle balance of forcings and processes acting on different timescales and partly in opposite direction as well as from memory effects associated with changes occurring during the termination (Menviel and Joos, 2011). Different interglacial periods with different forcing histories are thus expected to yield different $\mathrm{CO}_{2}$ and $\delta^{13} \mathrm{C}_{\mathrm{atm}}$ evolutions as documented by our measurements. In this respect, Termination I is special since it is characterised by the intermittent cooling during the YD event, which was also accompanied by an intermittent decline in terrestrial carbon storage (Köhler et al., 2005). This anomaly in terrestrial carbon storage during Termination I would also lead to a delay of the carbonate compensation signal in $\mathrm{CO}_{2}$ in the Holocene compared to MIS5.5. Accordingly, we attribute the increasing $\mathrm{CO}_{2}$ trend later in the Holocene and the lack of such a trend during MIS5.5 to the effect of carbonate compensation in response to the occurrence of the YD cold anomaly during Termination I. Both during Termination I and the subsequent early Holocene on the one side and Termination II plus the early MIS5.5 on the other side, $\delta^{13} \mathrm{C}_{\text {atm }}$ rises in total by about $0.4 \%$. Afterwards rather stable $\delta^{13} \mathrm{C}_{\mathrm{atm}}$ values are attained both in the later Holocene and in MIS5.5 until around $126000 \mathrm{yr}$ BP. After $126000 \mathrm{yr} \mathrm{BP}$ a further rise by $0.2 \%$ takes place which lasts until $120000 \mathrm{yr} \mathrm{BP}$. The latter could be at least partly explained by warmer sea surface temperatures at that time, which changes the fractionation during air/sea gas exchange, resulting in higher atmospheric $\delta^{13} \mathrm{C}_{\mathrm{atm}}$ values. Although in the EDC $\delta D$ record no warming is detected in the Southern Ocean region at that time, equatorial $\mathrm{Mg} / \mathrm{Ca}$-based SST change (Visser et al., 2003) and Northern Hemisphere temperature reconstructions based on a model-based deconvolution of benthic $\delta^{18} \mathrm{O}$ (Bintanja et al., 2005) reveal a local temperature increase of 1 to $1.5 \mathrm{~K}$ around $123000 \mathrm{yr} \mathrm{BP}$. A rise in temperature at $126000 \mathrm{yr} \mathrm{BP}$ could also trigger further terrestrial growth, which enriches $\delta^{13} \mathrm{C}_{\mathrm{atm}}$ even more. $\mathrm{As}_{\mathrm{CO}_{2}}$ concentrations reveal a constant level of $276 \mathrm{ppm}$ at that time, such a terrestrial build-up would have to be counterbalanced by other processes such as carbonate compensation. In the middle panels of Fig. 2 first-order SST-corrected evolutions in $\delta^{13} \mathrm{C}_{\mathrm{atm}}$ are indicated as well. Corrections are applied with respect to the LGM and PGM $\delta^{13} \mathrm{C}_{\text {atm }}$ values, respectively. $\delta^{13} \mathrm{C}_{\mathrm{atm}}$ corrections are derived from approximated SST evolutions (shown on a second ordinate) which represent the area-weighted mean from the individual changes in the Equatorial Pacific, Equatorial Atlantic, Southern Ocean, North Pacific and North Atlantic Ocean boxes (Köhler and Fischer, 2006). The SST corrected $\delta^{13} \mathrm{C}_{\mathrm{atm}}$ evolution along MIS5.5 supports the theory of an additional terrestrial build-up until $123000 \mathrm{yr} \mathrm{BP}$, as a net $\delta^{13} \mathrm{C}$ rise of about 0.1 to $0.2 \%$ remains after correcting for SST changes. Note that the marine records used for this correction are given on their individual age scales, which are different from the EDC3/TALDICE1a ages scale used for our ice core records. This could lead to erroneous $\delta^{13} \mathrm{C}_{\mathrm{atm}}$ changes in the SST-corrected version on a millennial timescale. Absolute magnitudes and evolutions in our SST corrected $\delta^{13} \mathrm{C}_{\mathrm{atm}}$ record highly depend on past temperature reconstructions, which suffer from regional differences and potential dating inconsistencies, as well as model specific assumptions and calculation limitations. Accordingly, the temperature correction is shown only to illustrate the physical effect of changing SST on $\delta^{13} \mathrm{C}_{\mathrm{atm}}$ and we refrain from quantitatively interpreting the millennial variations in the SST-corrected $\delta^{13} \mathrm{C}_{\mathrm{atm}}$ evolution in Fig. 2. In summary, $\mathrm{CO}_{2}$ and $\delta^{13} \mathrm{C}_{\mathrm{atm}}$ data are consistent with the same processes having been active during Termination II as Termination I, but with different strengths, timings and starting conditions. This sequence of events is comprised of (i) the up-welling of isotopically light water from the deep ocean starting at the onset of the termination accompanied by a decline in aeolian Fe fertilization; (ii) the increase in SST leading to higher $\mathrm{CO}_{2}$ and $\delta^{13} \mathrm{C}_{\mathrm{atm}}$; (iii) the regrowth of terrestrial biosphere starting in the second half of the transition, which ceases only a few thousand years into the following interglacial; (iv) the long-term effect of carbonate compensation. To explain the differences in the temporal evolution of carbon cycle changes during both Terminations and the subsequent interglacials the different temperature evolution during the terminations (such as the lack of a Younger Dryas cold 
spell in Termination II) have to be considered. Furthermore, other processes, such as changes in marine productivity or in the re-mineralisation depth of organic matter, nutrient release from shelves, shallow-water carbonate compensation or changes in ocean salinity, have likely contributed to the overall evolutions of atmospheric $\mathrm{CO}_{2}$ and $\delta^{13} \mathrm{C}$. A quantitative attribution of carbon cycle changes during Termination I and II cannot be achieved from our data only, however, our new $\delta^{13} \mathrm{C}_{\mathrm{atm}}$ record provides crucial data constraints for future carbon cycle model experiments.

\subsection{Lag of the $\mathrm{CO}_{2}$ decrease behind the temperature drop during the last glacial inception}

At $120000 \mathrm{yr} \mathrm{BP}$, Antarctic temperature begins to decline in Fig. 2 (Jouzel et al., 2007), whereas atmospheric $\mathrm{CO}_{2}$ concentration remains at a constant value of $276 \mathrm{ppm}$ for another $5000 \mathrm{yr}$. One may expect that the net uptake of $\mathrm{CO}_{2}$ by the ocean should follow Antarctic temperature based on the relatively high correlation between these two parameter over the past $800000 \mathrm{yr}$ (Fischer et al., 2010). Given the near constancy of atmospheric $\mathrm{CO}_{2}$ during the early inception, individual processes that increase or lower atmospheric $\mathrm{CO}_{2}$ must balance each other. Fischer et al. (1999) attributed the delayed response of $\mathrm{CO}_{2}$ mainly to the release of terrestrial carbon into the atmosphere, which counterbalances a transfer of $\mathrm{CO}_{2}$ to the deep ocean. In contrast, Hodell et al. (2001) attributed the continuously high $\mathrm{CO}_{2}$ levels to a delayed release of carbon from the ocean due to carbonate compensation induced from terrestrial biosphere build-up and ocean reorganization during Termination II and the early MIS5.5. The main difference between the two theories is that a release from biomass requires a net change in $\delta^{13} \mathrm{C}_{\mathrm{atm}}$, while the carbon isotopic signature of $\mathrm{CO}_{2}$ released by carbonate compensation hardly affects atmospheric $\delta^{13} \mathrm{C}_{\mathrm{atm}}$, as the released carbon originates from ocean DIC with $\delta^{13} \mathrm{C}$ between +2 and $+3 \%$, which is similar to surface waters in equilibrium with $\delta^{13} \mathrm{C}_{\mathrm{atm}}$. Note however that besides these two other processes, e.g. changes in ocean circulation or marine productivity act simultaneously and that a quantitative understanding demands a complete carbon cycle consideration. Our new data show $\delta^{13} \mathrm{C}_{\text {atm }}$ to be declining by $0.2 \%$ o between 120000 and $115000 \mathrm{yr} \mathrm{BP}$, thus taken at face value supporting the biosphere hypothesis. However, as SST decreases in parallel the solubility pump drags down $\mathrm{CO}_{2}$ and also induces an atmospheric fractionation to ${ }^{13} \mathrm{C}$ depleted values; $\delta^{13} \mathrm{C}_{\mathrm{atm}}$ is reduced by $0.1 \%$ as mean SST cools by $1 \mathrm{~K}$ (Mook, 1986, Zhang et al., 1995), hence a $0.2 \%$ decrease in $\delta^{13} C_{\text {atm }}$ as observed in our record would require a mean SST cooling by $2 \mathrm{~K}$ at that time. MARGO Project Members (2011) reported a global mean SST increase of only $1.9 \pm 1.8 \mathrm{~K}$, from the LGM to the Holocene; thus, it is unlikely that the $0.2 \%$ o drop in $\delta^{13} \mathrm{C}_{\mathrm{atm}}$ can be completely attributed to the much more subtle cooling between 120000 and $115000 \mathrm{yrBP}$. Moreover, the solubility effect would imply a reduction in atmospheric $\mathrm{CO}_{2}$ concentrations as well, which is not observed. Assuming that the entire $\delta^{13} \mathrm{C}_{\mathrm{atm}}$ effect is explained by the solubility effect, the carbon transfer from the atmosphere to the surface ocean has to be compensated by some other process as atmospheric $\mathrm{CO}_{2}$ concentrations remain unchanged. This could be due to carbon release from the terrestrial biosphere, which would add to the $\delta^{13} \mathrm{C}_{\mathrm{atm}}$ decrease, thus, would relax the required SST cooling. In summary, three mechanisms have to be considered: Colder SST draws down both atmospheric $\mathrm{CO}_{2}$ and $\delta^{13} \mathrm{C}_{\mathrm{atm}}$. As the terrestrial biosphere expanded during Termination II, it is reasonable to assume that the terrestrial carbon storage shrinks to some degree when temperatures decrease at the glacial inception. This release of terrestrial carbon induces further $\delta^{13} \mathrm{C}_{\mathrm{atm}}$ lowering. In total the reduction of $\mathrm{CO}_{2}$ due to the solubility effect has to be balanced by the release of terrestrial carbon into the atmosphere and/or carbon release from carbonate compensation while at the same time closing the $\delta^{13} \mathrm{C}$ budget. At the moment we cannot quantitatively decipher how much each of the processes discussed above contributed. A precise and ice core synchronized global SST reconstruction for this time period will be essential to better constrain the SST effect on $\delta^{13} \mathrm{C}_{\mathrm{atm}}$. Also global, higher resolution $\delta^{13} \mathrm{C}$ compilations for the deep and surface ocean over this time period could help to answer this question as a release of terrestrial carbon leads to a net decrease in $\delta^{13} \mathrm{C}$ in the ocean/atmosphere system.

\subsection{Understanding the $0.4 \%$ offset in $\delta^{13} \mathrm{C}_{\text {atm }}$ between the PGM and LGM}

$\delta^{13} \mathrm{C}_{\mathrm{atm}}$ during the LGM was on average about $0.4 \%$ o heavier than during the PGM. At the same time an enrichment of 0.2 to $0.4 \%$ for the mean ocean $\delta^{13} \mathrm{C}_{\mathrm{DIC}}$ change is recorded in many marine sediment cores (e.g. Hoogakker et al., 2007; Oliver et al., 2010). The change of the combined atmosphere/ocean system to ${ }^{13} \mathrm{C}$ enriched values suggests an overall shift of the isotopic signature of the combined ocean/atmosphere carbon stock. An overall $\delta^{13} \mathrm{C}$ shift of this reservoir has to be induced by fluctuations in the carbon fluxes entering and leaving the ocean/atmosphere system. In contrast, such an overall shift cannot be explained by ocean ventilation changes, which would enrich the surface ocean and deplete the deep ocean in $\delta^{13} \mathrm{C}_{\mathrm{DIC}}$. To discuss an overall long-term $\delta^{13} \mathrm{C}$ drift of the ocean/atmosphere system at orbital timescales the carbon fluxes into and out of the ocean/atmosphere system have to be considered. The main ingoing carbon fluxes are volcanic $\mathrm{CO}_{2}$ emission at subduction zones and mid ocean ridges, $\left(0.07-0.08 \mathrm{GtC} \mathrm{yr}^{-1}\right.$, Sano and Williams, 1996), carbonate weathering on the continents (0.1 to $0.2 \mathrm{GtCyr}^{-1}$, Archer et al., 1998; Zeebe and Westbroek, 2003) and mineralisation of old sedimentary organic carbon on continents and shelves $\left(0.06-0.12 \mathrm{Gt} \mathrm{yr}^{-1}\right.$, Zeebe and Caldeira, 2008). The main outgoing carbon fluxes are burial of carbonates in marine sediments and coral reefs as 
well as burial of organic matter on the ocean floor and on the continents. An important example of such partially buried carbon reservoirs on continents is the organic carbon stored in the deep permafrost and yedoma in high northern latitudes. The estimated amount of organic carbon in this region is large (1700 Gt C, Tarnocai et al., 2009), yet it is unclear when and at what rates this carbon was accumulated in the past and under what circumstances this carbon becomes remineralised and reintroduced into the ocean/atmosphere reservoir. Since all these carbon fluxes are small compared to the reservoir size of the ocean/atmosphere system, the mean residence time of carbon in the ocean/atmosphere system is estimated to be between 100000 and $150000 \mathrm{yr}$. In other words, after one glacial cycle $50-70 \%$ of the carbon is replaced by carbon. On the one hand this effect is able to produce a drift in the mean $\delta^{13} \mathrm{C}$ of the atmosphere/ocean system, on the other hand an imprinted $\delta^{13} \mathrm{C}$ signal (for instance caused by a growth in the terrestrial biosphere carbon storage) becomes gradually lost on these timescales. A long-term $\delta^{13} \mathrm{C}$ drift of the ocean/atmosphere system can result either from a change in these fluxes or in their isotopic $\delta^{13} \mathrm{C}$ signature or a combination of both. In the following, we want to discuss alternatives to explain the observed $0.4 \%$ offset in $\delta^{13} \mathrm{C}_{\mathrm{atm}}$ between the PGM and LGM: scenario (1) invokes differences in carbon fluxes and the corresponding isotopic signatures by carbonate weathering and sedimentation at the ocean floor; scenario (2) invokes changes in volcanic outgassing of $\mathrm{CO}_{2}$; and scenario (3) a net shift in the terrestrial carbon storage between the PGM and LGM (Lourantou et al., 2010b). Zeebe and Caldeira (2008) examined the effect of a long-term imbalance in carbon input and output fluxes on atmospheric $\mathrm{CO}_{2}$. They studied the hypothesis that carbon input into the ocean/atmosphere system by volcanism and net organic matter oxidation is balanced by silicate rock weathering and subsequent carbonate mineral burial. They argue that the mean decrease in atmospheric $\mathrm{CO}_{2}$ of $22 \mathrm{ppm}$ during the last $650000 \mathrm{yr}$ is due to an imbalance between carbon addition and removal with a net flux removing carbon from the ocean/atmosphere system. Interpolating over the last $150000 \mathrm{yr}$, this might account for the 5 to $10 \mathrm{ppm}$ concentration decline between the PGM and LGM. Stable carbon isotope signatures were not yet considered in the study by Zeebe and Caldeira (2008). Carbonate weathering causes a carbon flux entering the atmosphereocean reservoir of about 0.1 to $0.2 \mathrm{GtCyr}^{-1}$ possibly affecting $\delta^{13} \mathrm{C}$. Note that even if carbon fluxes are exactly balanced a change in the isotopic signature of the ocean/atmosphere system is possible, if ingoing and outgoing carbon fluxes do not carry the same isotopic signature. For example, the source could change as different rocks are weathered and with changing sources the carbon isotopic composition of the carbonate could also be altered (scenario (1)). Sedimentary carbonate rocks that are subject to continental weathering carry carbon isotopic signatures between 2 and 3\%o (Rubinson and Clayton, 1969, Emrich et al., 1970, Romanek et al., 1992), which would allow for a long-term trend in $\delta^{13} \mathrm{C}_{\mathrm{atm}}$. Unfortunately, there is not sufficient observational evidence available to reconstruct a change in the $\delta^{13} \mathrm{C}$ signature of the carbonate weathering. The second scenario (2) concentrates on the volcanic carbon release. According to Sano and Williams (1996) volcanic outgassing of $\mathrm{CO}_{2}$ releases about 0.07 to $0.08 \mathrm{GtCyr}^{-1}$. These inputs are assumed to be compensated by sedimentary carbonate burial in the ocean over timescales of thousands of years, which is controlled by the adaptation of the carbonate compensation depth in the ocean in response to changing riverine carbonate and alkalinity fluxes. Changing the ratio of the volcanic carbon flux via subduction along the continental crust relative to the release from mid-ocean-ridge basalt may shift the mean $\delta^{13} \mathrm{C}$ signature of the ocean-atmosphere carbon stock. Carbon released from mid-ocean-ridge regions $\left(\delta^{13} \mathrm{C} \sim-6.5 \%\right.$ ) shows ${ }^{13} \mathrm{C}$ depleted $\mathrm{CO}_{2}$ values relative to subduction areas by -1 to $-2 \%$ (Sano and Williams, 1996). Alternatively, a net global reduction of the volcanic carbon release results in enrichment of the mean $\delta^{13} \mathrm{C}$ input signal as the isotopic signature of the riverine input becomes more important. Hence, the PGM to LGM offset could also be induced by changed volcanic emissions. Roth and Joos (2012) found an upper limit of deglacial $\delta^{13} \mathrm{C}_{\mathrm{atm}}$ changes of -0.13 to $+0.12 \%$ induced by enhanced volcanic carbon outgassing. However, on timescales of a complete glacial cycle continuing changes in emission rates or isotopic signature of volcanic carbon fluxes might alter $\delta^{13} \mathrm{C}_{\mathrm{atm}}$ more strongly and induce longterm drifts. Note however that continuous changes in emission rate require other processes balancing $\mathrm{CO}_{2}$ concentrations. In the third scenario (3) a larger terrestrial carbon pool at the LGM compared to the PGM could cause a net shift in $\delta^{13} \mathrm{C}$. This could be due to a net change in the mid- and low latitude biomass or, more likely, by carbon locked away in permafrost soils. Studies on northern permafrost regions concerning amount and age of stored organic carbon suggested permafrost soil pool sizes of up to $1700 \mathrm{Gt} C$ (Tarnocai et al., 2009), with $88 \%$ being perennially frozen. Permafrost in the central Yukon region in Canada revealed ages older than $740000 \mathrm{yr}$ BP (Froese et al., 2008), showing that a long-term accumulation is possible. Also Reyes et al. (2010) claimed the persistence of deep discontinuous permafrost during the last $200000 \mathrm{yr}$. Such organic carbon pools represent a possibility to remove carbon from the ocean-atmosphere system on orbital timescales. A simple mass balance approach is performed in Eqs. (1) and (2) to quantify the necessary amount of carbon that has to be removed from the ocean-atmosphere carbon stock by organic carbon in permafrost to alter $\delta^{13} \mathrm{C}_{\mathrm{atm}}$ by $\Delta \delta_{\text {atm }}=0.4 \%$ as observed in our study and mean ocean $\delta^{13} \mathrm{C}$ by $\Delta \delta_{\text {DIC }}=0.2 \%$ to $0.4 \%$ (Oliver et al., 2010). Note that we allow different values for $\Delta \delta_{\text {atm }}$ and $\Delta \delta_{\text {DIC }}$ as internal ocean-atmosphere changes can potentially alter the $\delta^{13} \mathrm{C}$ difference between the ocean and atmosphere reservoirs. 


$$
\begin{aligned}
& \left(\Delta \delta_{\text {ocean }}+\delta_{\text {ocean }}^{\mathrm{PGM}}\right) \cdot\left(\mathrm{C}_{\text {ocean }}^{\mathrm{PGM}}+\Delta \mathrm{C}_{\text {ocean }}\right)+\left(\Delta \delta_{\mathrm{atm}}+\delta_{\mathrm{atm}}^{\mathrm{PGM}}\right) \\
& \cdot\left(\mathrm{C}_{\mathrm{atm}}^{\mathrm{PGM}}+\Delta \mathrm{C}_{\mathrm{atm}}\right) \\
& =\delta_{\text {ocean }}^{\mathrm{PGM}} \cdot \mathrm{C}_{\text {ocean }}^{\mathrm{PGM}}+\delta_{\mathrm{atm}}^{\mathrm{PGM}} \cdot \mathrm{C}_{\mathrm{atm}}^{\mathrm{PGM}}+\delta_{\text {terr }} \cdot \Delta \mathrm{C}_{\text {terr }} \\
& \mathrm{C}_{\text {ocean }}^{\mathrm{PGM}}+\Delta \mathrm{C}_{\text {ocean }}+\mathrm{C}_{\mathrm{atm}}^{\mathrm{PGM}}+\Delta \mathrm{C}_{\mathrm{atm}}=\mathrm{C}_{\text {ocean }}^{\mathrm{PGM}}+\mathrm{C}_{\mathrm{atm}}^{\mathrm{PGM}} \\
& +\Delta \mathrm{C}_{\text {terr }}
\end{aligned}
$$

Changes of total organic carbon, rain ratio and marine production are not considered in the following, essentially assuming that these processes acted in a comparable way both during the last and the penultimate glacial. Furthermore, the isotopic signature of formed biomass $\Delta \mathrm{C}_{\text {terr }}$ is assumed to remain constant at $\delta_{\text {terr }}=-28 \%$, representative of the C3 plant metabolism in high latitudes (Novak et al., 1999; Dioumaeva et al., 2003). Hence this calculation represents a minimum flux scenario for a terrestrial carbon source of distinct isotopic signature. To quantify the atmospheric carbon reservoir during the $\mathrm{PGM} \mathrm{C}_{\mathrm{atm}}^{\mathrm{PG}}$, as well as the change between PGM and LGM $\Delta \mathrm{C}_{\mathrm{atm}}$, atmospheric $\mathrm{CO}_{2}$ concentration is converted to $\mathrm{GtC}$. One ppm corresponds to $2.123 \mathrm{GtC}$. The size of the LGM ocean carbon stock $\mathrm{C}_{\text {ocean }}^{\text {PGM }}$ is set to $39400 \mathrm{GtC}$ (Köhler et al., 2005). Our new $\delta^{13} \mathrm{C}_{\mathrm{atm}}$ data show stable carbon isotope values of $\delta_{\text {atm }}^{\mathrm{PGM}}=-6.8 \%$ at the PGM. The ocean value is set to $\delta_{\text {ocean }}^{\mathrm{PGM}}=-0.5 \%$ (Oliver et al., 2010). Using this mass balance approach we can quantify the amount of carbon required to explain a $0.4 \%$ offset. However, in this mass balance scenario we assume an instantaneous shift from the PGM to the LGM time window. In reality the time intervals are about $120000 \mathrm{yr}$ apart. Accordingly, part of the carbon anomaly will be removed over time by the continuous replacement of carbon in the biosphere/ocean/atmosphere system by the carbonate weathering and volcanic carbon input flux on the one hand and sediment burial on the other. Summing up these fluxes, between 0.274 to $0.344 \mathrm{GtC}$ enter and leave the ocean-atmosphere system during one year and the complete ocean-atmosphere carbon pool is recycled once in less than $150000 \mathrm{yr}$. Thus, after $120000 \mathrm{yr}$ only a small fraction of the $\delta^{13} \mathrm{C}$ anomaly is preserved. Approximations using the Bern3D climate model of intermediate complexity lead to a preservation of $25 \%$ of any $\delta^{13} \mathrm{C}$ anomaly after $100000 \mathrm{yr}$ (Schneiter, 2011). For a maximum estimate we assume that this isotopic attenuation process is switched off, i.e. $100 \%$ of the anomaly are preserved. Results of the mass balance above, which account for the isotopic attenuation by the sedimentary turn-over of carbon, are shown in Fig. 4. The green curve in the centre is calculated for changes in oceanic $\Delta \delta_{\text {ocean }}=0.3 \%$, whereas the black envelopes result from $\Delta \delta_{\text {ocean }}=0.2 \%$ and $0.4 \%$, respectively. The errors for the isotopic value of the deep ocean $\delta_{\text {ocean }}^{\mathrm{PGM}}$ and the ocean carbon storage $\mathrm{C}_{\text {ocean }}^{\mathrm{PGM}}$ are negligible compared to the unknown rate of signal attenuation. In the case of $25 \%$ signal preservation, 1000 to $2000 \mathrm{Gt} \mathrm{C}$ have to be transferred from the ocean-atmosphere system to the

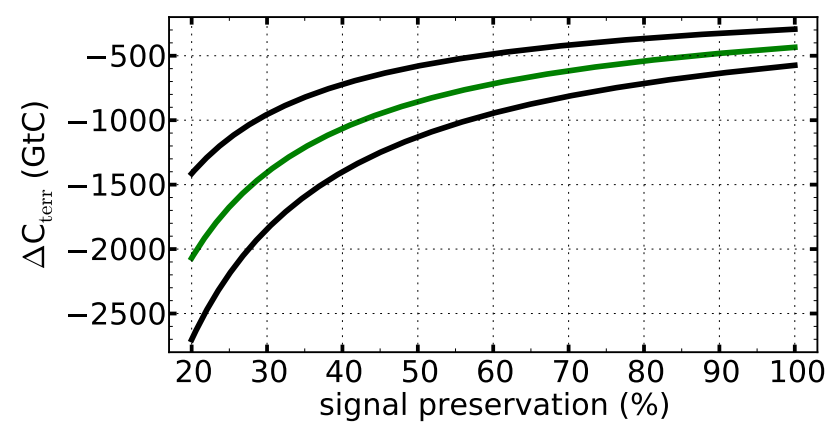

Fig. 4. Mass balance calculation for a potential change in terrestrial carbon storage from the PGM to the LGM: The plot shows the necessary carbon amount in $\mathrm{GtC}$ that has to be withdrawn (see Eq. 1) from the ocean-atmosphere system and transferred to the land carbon pool if $\delta^{13} \mathrm{C}_{\mathrm{atm}}$ shifted by $0.4 \%$ and mean ocean $\delta^{13} \mathrm{C}_{\mathrm{DIC}}$ changed by either $0.2 \%$ (top black line), $0.3 \%$ (middle green line) or $0.4 \%$ (bottom black line), respectively, between the PGM and the LGM dependent on the degree of isotopic attenuation due to the weathering influx (compare main text). The isotopic signature of peat biomass is assumed to be $\delta_{\text {terr }} \sim-28 \%$. A signal preservation of $100 \%$ corresponds to no isotope attenuation.

terrestrial carbon pool to explain the $0.4 \%$ offset in $\delta^{13} \mathrm{C}_{\mathrm{atm}}$ between LGM and PGM as shown in Fig. 4. Such a range may still be realistic in the framework of the permafrost reconstructions by Froese et al. (2008), Tarnocai et al. (2009) and Reyes et al. (2010). In contrast, if we assume a change in biomass in low and middle latitudes with a typical $\delta^{13} \mathrm{C}_{\text {terr }}$ signature of $-22 \%$ for the LGM (Francois et al., 1998), thus significantly heavier than carbon locked in permafrost, the total amount of additional stored terrestrial carbon required to explain the $\delta^{13} \mathrm{C}$ anomaly in the PGM for $25 \%$ preservation increases to more than $2000 \mathrm{GtC}$ (not shown). This is on the same order as the total carbon stored in living biomass and soils today and is approximately a factor of 4 larger than the net change in the terrestrial carbon storage from the LGM to the Holocene. Accordingly, such an increase in non-permafrost terrestrial carbon is most likely too large and unlikely to be able to account for the $\delta^{13} \mathrm{C}$ anomaly. Hence, permafrost represent the most likely candidate to lock away such terrestrial carbon on timescales of $10000 \mathrm{yr}$ and more. From our new data we also conclude that the major part of such a possible increase in terrestrial carbon storage did not occur during MIS5.5 as $\delta^{13} \mathrm{C}_{\text {atm }}$ still was $0.2 \%$ lower at $100000 \mathrm{yr} \mathrm{BP}$ compared to the LGM $(0.4 \%$ in the SST corrected records). Hence, the major part of this biomass accumulation must have occurred after MIS5.5 but before the LGM. Note that changes in the amount of carbon stored in the methane hydrate reservoirs may represent a further possibility to explain the difference between the two periods. To assess this potential influence, the overall methane hydrate reservoir size is an important point. Current estimates are 500 to $2500 \mathrm{GtC}$ (Milkov, 2004). Redoing the same mass balance 
calculation as done above at an assumed signal preservation of $50 \%$ but an isotopic signature of $-60 \%$ (representative for methane hydrates) instead of $-28 \%$ reveals a necessary hydrate buildup (or release reduction) of about $500 \mathrm{GtC}$ to account for the $0.4 \%$ o shift between PGM and LGM. In the frame of the estimates by Milkov (2004), this number would require that $20-100 \%$ of the carbon stored in hydrates would have been built up during the last $100000 \mathrm{yr}$, which appears to be unrealistically large. However, we acknowledge that using older, larger estimates of the hydrate reservoir would make this scenario more likely. Moreover, Fehn et al. (2000) report that today's methane hydrates were formed millions of years before the time interval discussed in this paper. This would be at odds with relatively young hydrate accumulated during the last $100000 \mathrm{yr}$. As sea level and temperature conditions during the PGM and the LGM were not too different (Lisiecki and Raymo, 2005; Jouzel et al., 2007), it also appears unlikely that there was a major change between these two time intervals in the stability conditions for marine hydrates and, thus, their reservoir size. Hence, methane hydrates represent a further possibility to account for the measured $\delta^{13} \mathrm{C}$ offset, and our data per se cannot rule out such a scenario, however, in the bigger picture of hydrate amount and age, we regard a major influence on the PGM/LGM difference in $\delta^{13} C_{\text {atm }}$ as rather unlikely. In summary, our new data confirm the PGM to LGM shift as reported in Lourantou et al. (2010b), but show a larger magnitude. Based on current knowledge, it is not possible to exclude one of the three explanation approaches of (1) changes in carbon isotope fluxes of carbonate weathering and sedimentation at the sea floor, (2) varying contributions from volcanic outgassing or (3) peat and permafrost carbon build-up that would be conserved till present days. In contrast, the required net growth of terrestrial biomass outside of permafrost regions is probably too large to explain the offset and also a respective change in the methane hydrate reservoir from the PGM to the LGM is hard to envisage.

\section{Conclusions}

Using ice core measurements of atmospheric $\delta^{13} \mathrm{C}_{\mathrm{atm}}$, we are able to better constrain the possible pathways of the global carbon cycle evolution in the past. First-order interpretation of our new data for the penultimate glacial/interglacial transition shows that the same processes influence the global carbon cycle at that time as already reported for the last $24000 \mathrm{yr}$, however with different magnitude, timing and starting conditions. The early MIS5.5 is dominated by a build-up of land biosphere and increased preservation of calcium carbonate in the ocean. In this respect it is interesting to note that the different temporal evolution of $\mathrm{CO}_{2}$ in the Holocene and in MIS5.5 does not require an extraordinary anthropogenic source of carbon into the atmosphere (Ruddiman et al., 2003), but can be explained by the different temporal evolution of the carbon cycle during the preceding deglaciation. The unique Younger Dryas climate event during Termination I, which has no comparable counterpart during Termination II, together with the long-term memory of the carbon cycle through carbonate compensation have to be considered to explain the increasing $\mathrm{CO}_{2}$ levels during the Holocene (Elsig et al., 2009), while such an increase is not observed during MIS5.5. The appearance of a minimum in $\delta^{13} \mathrm{C}_{\mathrm{atm}}$ during the late MIS5.5, likely induced by a terrestrial carbon release and colder SST, can explain stable $\mathrm{CO}_{2}$ levels for many thousand years, when Antarctic temperatures already declined. However, the amount of carbon released from the biosphere at that time cannot be quantified with certainty, since carbonate compensation may have also contributed to $\mathrm{CO}_{2}$ emissions into the atmosphere. A reason for an observed offset between the mean values in $\delta^{13} \mathrm{C}_{\mathrm{atm}}$ of the current and last interglacials cannot unambiguously be assigned. A build-up of permafrost by 1000 to $2000 \mathrm{GtC}$ with a $\mathrm{C} 3$ plant isotopic signature is one possible scenario to explain the observed shifts between LGM and PGM in atmospheric $\mathrm{CO}_{2}$ and $\delta^{13} \mathrm{C}_{\text {atm }}$, while changes in terrestrial carbon stocks other than in permafrost are unlikely to account for the observed $\delta^{13} \mathrm{C}$ change. Furthermore, a temporal change in the isotopic ratio of carbonate weathering between the end of the previous interglacial and the last glacial maximum or fluctuations in the contributions from volcanic input fluxes may provide alternative explanations. A future continuous record of $\delta^{13} \mathrm{C}$ changes over the entire last glacial cycle connecting the MIS5.5 with the LGM will be key to better understand these long-term changes in carbon (isotope) imbalances. Moreover, reliable reconstructions of global changes in $\delta^{13} \mathrm{C}_{\text {DIC }}$ will provide another powerful constraint on carbon cycle changes over these timescales (Goodwin et al., 2011). Furthermore extensive three dimensional dynamical ocean modelling on a regional and global scale, including all relevant carbon cycle processes and dynamic input/output fluxes of carbonate and silicate weathering, volcanic emission and $\mathrm{CaCO}_{3}$ fluxes into the sediments, are crucial as carbon cycle fluxes are not decoupled from each other.

Acknowledgements. This work is a contribution to the European Project for Ice Coring in Antarctica (EPICA), a joint European Science Foundation/European Commission scientific program, funded by the EU (EPICA-MIS) and by national contributions from Belgium, Denmark, France, Germany, Italy, the Netherlands, Norway, Sweden, Switzerland and the United Kingdom as well as to the "TALos Dome Ice CorE" (TALDICE) project funded by Italy, France, Germany, Switzerland and United Kingdom. The main EPICA logistic support was provided by IPEV and PNRA (at Dome C) and AWI (at Dronning Maud Land). This work is also a contribution to the EU Integrated Programme "Past4Future: Climate change - Learning from the past climate" within the European Union's Seventh Framework programme (FP7/20072013) under grant agreement no. 243908. We thank A. Landais, D. Rodriguez, E. Capron and G. Dreyfus for the contribution of $\delta^{15} \mathrm{~N}$ 
data. We acknowledge financial support by the Swiss NSF, the DFG priority program INTERDYNAMIK and the German climate program DEKLIM. We thank J. Chappellaz for many discussions on $\delta^{13} \mathrm{C}_{\text {atm }}$ in ice cores and E. W. Wolff for discussions on the impact of climate variations during glacial/interglacial terminations on carbonate compensation effects in the subsequent warm periods. This is EPICA publication no. 292 and TALDICE publication no. 33 .

Edited by: K. Kawamura

\section{References}

Ahn, J., Brook, E., Schmittner, A., and Kreutz, K. J.: Abrupt change in atmospheric $\mathrm{CO}_{2}$ during the last ice age, Geophys. Res. Lett., 39, L18711, doi:10.1029/2011GB004247, 2012.

Anderson, R. F., Ali, S., Bradmiller, L. I., Nielsen, S. H. H., Fleisher, M. Q., Anderson, B. E., and Burckle, L. H.: Winddriven upwelling in the Southern Ocean and the deglacial rise in atmospheric $\mathrm{CO}_{2}$, Science, 323, 1443-1448, 2009.

Archer, D., Kheshgi, H., and Maier-Reimer, E.: Dynamics of fossil fuel neutralization by marine $\mathrm{CaCO}_{3}$, Global Biogeochem. Cy., 12, 259-276, 1998.

Barker, S. and Elderfield, H.: Foraminiferal calcification response to glacial-interglacial changes in atmospheric $\mathrm{CO}_{2}$, Science, 297 , 833-836, 2002.

Barker, S., Kiefer, T., and Elderfield, H.: Temporal changes in North Atlantic circulation constrained by planktonic foraminiferal shell weights, Paleoceanography, 19, PA3008, doi:10.1029/2004PA001004, 2004.

Bereiter, B., Schwander, J., Lüthi, D., and Stocker, T. F.: Changes in $\mathrm{CO}_{2}$ concentration and $\mathrm{O}_{2} / \mathrm{N}_{2}$ ratio in ice cores due to molecular diffusion, Geophys. Res. Lett., 36, L05703, doi:10.1029/2008GL036737, 2009.

Bereiter, B., Lüthi, D., Siegrist, M., Schüpbach, S., Stocker, T. F., and Fischer, $\mathrm{H}$.: Mode change of millenial $\mathrm{CO}_{2}$ variability during the last glacial cycle associated with a bipolar marine carbon seesaw, Proc. Natl. Acad. Sci., 109, 9755-9760, 2012.

Bintanja, R., van de Wal, R., and Oerlemans, J.: Modelled atmospheric temperatures and global sea levels over the past million years, Nature, 437, 125-128, 2005.

Boden, T. A., Marland, G., and Andres, R. J.: Global, Regional, and National Fossil-Fuel $\mathrm{CO}_{2}$ Emissions, Carbon Dioxide Information Analysis Center, Oak Ridge National Laboratory, US Department of Energy, Oak Ridge, Tenn., USA, 2011.

Broecker, W. S. and Clark, E.: Holocene atmospheric $\mathrm{CO}_{2}$ increase as viewed from the seafloor, Global Biogeochem. Cy., 17, 1052, doi:10.1029/2002GB001985, 2003.

Broecker, W. S., Lao, Y., Klas, M., Clark, E., Bonani, G., Ivy, S., and Chen, C.: A search for an early holocene $\mathrm{CaCO}_{3}$ preservation event, Paleoceanography, 8, 333-339, 1993.

Broecker, W. S., Clark, E., McCorkle, D. C., Peng, T.-H., Hajdas, I., and Bonani, G.: Evidence for a reduction in the carbonate ion content of the deep sea during the course of the holocene, Paleoceanography, 14, 744-752, 1999.

Brovkin, V., Ganopolski, A., Archer, D., and Rahmstorf, S.: Lowering of glacial atmospheric $\mathrm{CO}_{2}$ in response to changes in oceanic circulation and marine biogeochemistry, Paleoceanography, 22, PA4202, doi:10.1029/2006PA001380, 2007.
Buiron, D., Chappellaz, J., Stenni, B., Frezzotti, M., Baumgartner, M., Capron, E., Landais, A., Lemieux-Dudon, B., MassonDelmotte, V., Montagnat, M., Parrenin, F., and Schilt, A.: TALDICE-1 age scale of the Talos Dome deep ice core, East Antarctica, Clim. Past, 7, 1-16, doi:10.5194/cp-7-1-2011, 2011.

Capron, E., Landais, A., Chappellaz, J., Schilt, A., Buiron, D., DahlJensen, D., Johnsen, S. J., Jouzel, J., Lemieux-Dudon, B., Loulergue, L., Leuenberger, M., Masson-Delmotte, V., Meyer, H., Oerter, H., and Stenni, B.: Millennial and sub-millennial scale climatic variations recorded in polar ice cores over the last glacial period, Clim. Past, 6, 345-365, doi:10.5194/cp-6-3452010, 2010.

Clark, P. U., Dyke, A. S., Shakun, J. D., Carlson, A. E., Clark, J., Wohlfarth, B., Mitrovica, J. X., Hostetler, S. W., and McCabe, A. M.: The Last Glacial Maximum, Science, 325, 710 714, 2009.

Cuffey, K. and Vimeux, F.: Covariation of carbon dioxide and temperature from the Vostok ice core after deuterium-excess correction, Nature, 412, 523-527, doi:10.1038/35087544, 1991.

Delmonte, B., Baroni, C., Andersson, P. S., Schoberg, H., Hansson, M., Aciego, S., Petit, J., Albani, S., Mazzola, C., Maggi, V., and Frezzotti, M.: Aeolian dust in the Talos Dome ice core (East Antarctica, Pacific/Ross Sea sector): Victoria Land versus remote sources over the last two climate cycles, J. Quaternary Sci., 25, 1327-1337, 2010.

Dioumaeva, I., Trumbore, S., Schuur, E. A. G., Goulden, M. L., Litvak, M., and Hirsch, A. I.: Decomposition of peat from upland boreal forest: Temperature dependence and sources of respired carbon, J. Geophys. Res., 108, 8222, doi:10.1029/2001JD000848, 2003.

Dreyfus, G. B.: Dating an 800000 years Antarctic ice core record using the isotopic composition of trapped air, Ph.D. Thesis, Princeton University, 2008.

Ehleringer, J. R., Hall, A. E., and Farquhar, G. D. (Eds.): Stable Isotopes and Plant Carbon-Water Relations, Physiological Ecology Series, San Diego, Calif., Academic Press, 1993.

Elsig, J., Schmitt, J., Leuenberger, D., Schneider, R., Eyer, M., Leuenberger, M., Joos, F., Fischer, H., and Stocker, T. F.: Stable isotope constraints on Holocene carbon cycle changes from an Antarctic ice core, Nature, 461, 507-510, 2009.

Emrich, K., Ehhalt, D. H., and Vogel, J. C.: Carbon isotope fractionation during the precipitation of calcium carbonate, Earth Planet. Sci. Lett., 8, 363-371, 1970.

Enting, I. G.: On the use of smoothing splines to filter $\mathrm{CO}_{2}$ data, J. Geophys. Res., 92, 10977-10984, 1987.

Etheridge, D. M., Steele, L. P., Langenfelds, R. L., Francey, R. J., Barnola, J.-M., and Morgan, V. I.: Natural and anthropogenic changes in atmospheric $\mathrm{CO}_{2}$ over the last 1000 years from air in Antarctic ice and firn, J. Geophys. Res., 101, 4115-4128, 1996.

Farrell, J. W. and Prell, W. L.: Climatic change and $\mathrm{CaCO}_{3}$ preservation: An 800000 year bathymetric reconstruction from the central equatorial Pacific ocean, Paleoceanography, 4, 447-466, 1989.

Fehn, U., Snyder, G., and Egeberg, P. K.: Dating of Pore Waters with 129I: Relevance for the Origin of Marine Gas Hydrates, Science 289, 5488, doi:10.1126/science.289.5488.2332, 2000.

Fischer, H., Wahlen, M., Smith, J., Mastroianni, D., and Bruce, D.: Ice core records of atmospheric $\mathrm{CO}_{2}$ around the last three glacial terminationsq, Science, 283, 1712-1714, 1999. 
Fischer, H., Schmitt, J., Lüthi, D., Stocker, T. F., Tschumi, T., Parekh, P., Joos, F., Köhler, P., Völker, C., Gersonde, R., Barbante, C., Floch, M. L., Raynaud, D., and Wolff, E.: The role of Southern Ocean processes on orbital and millennial $\mathrm{CO}_{2}$ variations - a synthesis, Quaternary Sci. Rev., 29, 193-205, 2010.

Francey, R., Michel, E., Etheridge, D. M., Allison, C. E., Leuenberger, M. L., and Raynaud, D.: The preindustrial difference in $\mathrm{CO}_{2}$ from Antarctic and Greenland ice (AB0170), Fifth International Carbon Dioxid Conference, Cairns, Queensland, Australia, 8-12 September, 1997.

Francey, R. J., Allison, C. E., Etheridge, D. M., Trudinger, C. M., Enting, I. G., Leuenberger, M., Langenfelds, R., Michel, E., and Steele, L. P.: A 1000 year high precision record of $\delta^{13} \mathrm{C}$ in atmospheric $\mathrm{CO}_{2}$, Tellus B, 51, 170-193, 1999.

François, L. M., Delire, C., Warnant, P., and Munhoven, G.: Modelling the glacial-interglacial changes in the continental biosphere, Glob. Planet. Change, 16-17, 37-52, 1998.

François, R., Altabet, M. A., Yu, E.-F., Sigman, D. M., Pacon, M. P., Frankl, M., Bohrmann, G., Bareille, G., and Labeyrie, L. D.: Contribution of Southern Ocean surface-water stratification to low atmospheric $\mathrm{CO}_{2}$ concentrations during the last glacial period, Nature, 389, 929-935, 1997.

Froese, D. G., Westgate, J. A., Reyes, A. V., Enkin, R. J., and Preece, S. J.: Ancient permafrost and a future, warmer Arctic, Science, 321, 5896, doi:10.1126/science.1157525, 2008.

Goodwin, P., Oliver, K. I. C., and Lenton, T. M.: Observational constraints on the causes of Holocene $\mathrm{CO}_{2}$ change, Global Biogeochem. Cy., 25, GB3011, doi:10.1029/2010GB003888, 2011.

Hodell, D. A., Charles, C. D., and Sierro, F. J.: Late Pleistocene evolution of the ocean's carbonate system, Earth Planet. Sci. Lett., 192, 109-124, 2001.

Hodell, D. A., Venz, K. A., Charles, C. D., and Ninnemann, U. S.: Pleistocene vertical carbon isotope and carbonate gradients in the South Atlantic sector of the Southern Ocean, Geochem. Geophys. Geosys., 4, 1004, doi:10.1029/2002GC000367, 2003.

Hoogakker, B. A. A., Rohling, E. J., Palmer, M. R., Tyrrell, T., and Rothwell, R. G.: Underlying causes for long-term global ocean $\delta^{13} \mathrm{C}$ fluctuations over the last 1.20 Myr, Earth Planet. Sci. Lett., 248, 15-29, 2006.

Houghton, R. A.: How well do we know the flux of $\mathrm{CO}_{2}$ from landuse change?, Tellus B, 62, 337-351, 2010.

Indermühle, A., Stocker, T. F., Joos, F., Fischer, H., Smith, H. J., Wahlen, M., Deck, B., Mastroianni, D., Tschumi, J., Blunier, T., Meyer, R., and Stauffer, B.: Holocene carbon-cycle dynamics based on $\mathrm{CO}_{2}$ trapped in ice at Taylor Dome, Antarctica, Nature, 398, 121-126, 1999.

Joos, F. and Spahni, R.: Rates of change in natural and anthropogenic radiative forcing over the past 20000 years, Proc. Natl. Acad. Sci., 105, 1425-1430, 2008.

Jouzel, J., Vaikmae, R., Petit, J. R., Martin, M., Duclos, Y., Stievenard, M., Lorius, C., Toots, M., Mélières, M. A., Burckle, L. H., Barkov, N. I., and Kotlyakov, V. M.: The two-step shape and timing of the last deglaciation in Antarctica, Clim. Dynam., 11, 3, 151-161, 1995.

Jouzel, J., Masson-Delmotte, V., Cattani, O., Dreyfus, G., Falourd, S., Hoffmann, G., Minster, B., Nouet, J., Barnola, J. M., Chappellaz, J., Fischer, H., Gallet, J. C., Johnsen, S., Leuenberger, M., Loulergue, L., Lüthi, D., Oerter, H., Parrenin, F., Raisbeck, G., Raynaud, D., Schilt, A., Schwander, J., Selmo, E.,
Souchez, R., Spahni, R., Stauffer, B., Steffensen, J. P., Stenni, B., Stocker, T. F., Tison, J. L., Werner, M., and Wolff, E. W.: Orbital and millennial antarctic climate variability over the past 800000 years, Science, 317, 793-797, 2007.

Kawamura, K., Parrenin, F., Lisiecki, L., Uemura, R., Vimeux, F., Severinghaus, J. P., Hutterli, M. A., Nakazawa, T., Aoki, S., Jouzel, J., Raymo, M. E., Matsumoto, K., Nakata, H, Motoyama, H., Fujita, S., Goto-Azuma, K., Fujii, Y., and Watanabe, O.: Northern Hemisphere forcing of climatic cycles in Antarctica over the past 360000 years, Nature, 448, 912-916, 2007.

Keeling, R. F., Piper, S. C., Bollenbacher, A. F., and Walker, J. S.: Atmospheric $\mathrm{CO}_{2}$ records from sites in the SIO air sampling network, in: Trends: A Compendium of Data on Global Change, Carbon Dioxide Information Analysis Center, Oak Ridge National Laboratory, US Department of Energy, Oak Ridge, Tenn., USA doi:10.3334/CDIAC/atg.035, 2009.

Keeling, R. F., Piper, S. C., Bollenbacher, A. F., and Walker, S. J.: Monthly atmospheric ${ }^{13} \mathrm{C} /{ }^{13} \mathrm{C}$ isotopic ratios for $11 \mathrm{SIO}$ stations, in: Trends: A Compendium of Data on Global Change, Carbon Dioxide Information Analysis Center, Oak Ridge National Laboratory, US Department of Energy, Oak Ridge, Tenn., USA, 2010.

Kleinen, T., Brovkin, V., Von Bloh, W., Archer, D., and Munhoven, G.: Holocene carbon cycle dynamics, Geophys. Res. Lett., 37, L02705, doi:10.1029/2009GL041391, 2010.

Köhler, P. and Fischer, H.: Simulating low frequency changes in atmospheric $\mathrm{CO}_{2}$ during the last 740000 years, Clim. Past, 2, 57-78, doi:10.5194/cp-2-57-2006, 2006.

Köhler, P., Fischer, H., Munhoven, G., and Zeebe, R. A.: Quantitative interpretation of atmospheric carbon records over the last glacial termination, Global Biogeochem. Cy., 19, GB4020, doi:10.1029/2004GB002345, 2005.

Köhler, P., Fischer, H., Schmitt, J., and Munhoven, G.: On the application and interpretation of Keeling plots in paleo climate research - deciphering $\delta^{13} \mathrm{C}$ of atmospheric $\mathrm{CO}_{2}$ measured in ice cores, Biogeosciences, 3, 539-556, doi:10.5194/bg-3-539-2006, 2006.

Köhler, P., Fischer, H., and Schmitt, J.: Atmospheric $\delta^{13} \mathrm{CO}_{2}$ and its relation to $\mathrm{pCO}_{2}$ and deep ocean $\delta^{13} \mathrm{C}$ during the late Pleistocene, Paleoceanography 25, PA1213, doi:10.1029/2008PA001703, 2010.

Köhler, P., Knorr, G., Buiron, D., Lourantou, A., and Chappellaz, J.: Abrupt rise in atmospheric $\mathrm{CO}_{2}$ at the onset of the Bølling/Allerød: in-situ ice core data versus true atmospheric signals, Clim. Past, 7, 473-486, 2011, http://www.clim-past.net/7/473/2011/.

Kopp, R. E., Simons, F. J., Mitrovica, J. X., Maloof, A. C., and Oppenheimer, M.: Probabilistic assessment of sea level during the last interglacial stage, Nature, 462, 863-867, 2009.

Lambert, F., Bigler, M., Steffensen, J. P., Hutterli, M., and Fischer, H.: Centennial mineral dust variability in high-resolution ice core data from Dome C, Antarctica, Clim. Past, 8, 609-623, doi:10.5194/cp-8-609-2012, 2012.

Landais, A., Rodriguez, D., Capron, E. and Dreyfus, G.: in preparation, 2013.

Leuenberger, M., Siegenthaler, U., and Langway, C. C.: Carbon isotope composition of atmospheric $\mathrm{CO}_{2}$ during the last ice age from an Antarctic ice core, Nature, 357, 488-490, 1992. 
Lisiecki, L. E. and Raymo, M. E.: A Pliocene-Pleistocene stack of 57 globally distributed benthic $\delta^{18} \mathrm{O}$ records. Paleoceanography, 20, PA1003, doi:10.1029/2004PA001071, 2005.

Loulergue, L., Parrenin, F., Blunier, T., Barnola, J.-M., Spahni, R., Schilt, A., Raisbeck, G., and Chappellaz, J.: New constraints on the gas age-ice age difference along the EPICA ice cores, 0-50 kyr, Clim. Past, 3, 527-540, doi:10.5194/cp-3-527-2007, 2007.

Lourantou, A., Lavric, J. V., Köhler, P., Barnola, J. M., Paillard, D., Michel, E., Raynaud, D., and Chappellaz, J.: Constraint of the $\mathrm{CO}_{2}$ rise by new atmospheric carbon isotopic measurements during the last deglaciation, Global Biogeochem. Cy., 24, GB2015, doi:10.1029/2009GB003545, 2010a.

Lourantou, A., Chappellaz, J., Barnola, J. M., Masson-Delmotte, V., and Raynaud, D.: Changes in atmospheric $\mathrm{CO}_{2}$ and its carbon isotopic ratio during the penultimate deglaciation, Quaternary Sci. Rev., 29, 1983-1992, doi:10.1016/j.quascirev.2010.05.002, 2010b.

Lüthi, D., Bereiter, B., Stauffer, B., Winkler, R., Schwander, J., Kindler, P., Leuenberger, M., Kipfstuhl, S., Capron, E., Landais, A., Fischer, H., and Stocker, T. F.: $\mathrm{CO}_{2}$ and $\mathrm{O}_{2} / \mathrm{N}_{2}$ variations in and just below the bubble-clathrate transformation zone of Antarctic ice cores, Earth Planet. Sci. Lett., 297, 1-2, 226233, 2010.

MARGO Project Members: Constraints on the magnitude and patterns of ocean cooling at the Last Glacial Maximum, Nat. Geosci., 2011, 2, 127-132, 2009.

Menviel, L. and Joos, F.: Toward explaining the Holocene carbon dioxide and carbon isotope records: results from transient ocean carbon cycle-climate simulations, Paleoceanography, 27, PA1207, doi:10.1029/2011PA002224, 2012.

Menviel, L., Joos, F., and Ritz, S. P.: Simulating atmospheric $\mathrm{CO}_{2},{ }^{13} \mathrm{C}$ and the marine carbon cycle during the Last GlacialInterglacial cycle: possible role for a deepening of the mean remineralization depth and an increase in the oceanic, Quaternary Sci. Rev., 56, 46-68, 2012.

Milkov, A. V.: Global estimates of hydrate-bound gas in marine sediments: How much is really out there?, Earth-Sci. Rev., 66, 183197, doi:10.1016/j.earscirev.2003.11.002, 2004.

Monnin, E., Indermühle, A., Dallenbach, A., Flückiger, J., Stauffer, B., Stocker, T. F., Raynaud, D., and Barnola, J. M.: Atmospheric $\mathrm{CO}_{2}$ Concentrations over the Last Glacial Termination, Science, 291, 112-114, 2001.

Mook, W. G.: ${ }^{13} \mathrm{C}$ in atmospheric $\mathrm{CO}_{2}$, Neth. J. Sea Res., 20, $211-$ 223, 1986.

Novak, M., Buzek, F., and Adamova, M.: Vertical trends in $\delta^{13} \mathrm{C}, \delta^{15} \mathrm{~N}$ and $\delta^{34} \mathrm{~S}$ ratios in bulk Sphagnum peat, Soil Biol. Biochem., 31, 1343-1346, 1999.

O'Leary, M. H.: Carbon isotope fractionation in plants, Phytochemistry, 20, 4, 553-567, 1981.

Oliver, K. I. C., Hoogakker, B. A. A., Crowhurst, S., Henderson, G. M., Rickaby, R. E. M., Edwards, N. R., and Elderfield, H.: A synthesis of marine sediment core $\delta^{13} \mathrm{C}$ data over the last 150000 years, Clim. Past, 6, 645-673, doi:10.5194/cp-6-6452010, 2010.

Parrenin, F., Barnola, J.-M., Beer, J., Blunier, T., Castellano, E., Chappellaz, J., Dreyfus, G., Fischer, H., Fujita, S., Jouzel, J., Kawamura, K., Lemieux-Dudon, B., Loulergue, L., MassonDelmotte, V., Narcisi, B., Petit, J.-R., Raisbeck, G., Raynaud, D., Ruth, U., Schwander, J., Severi, M., Spahni, R., Steffensen, J. P.,
Svensson, A., Udisti, R., Waelbroeck, C., and Wolff, E.: The EDC3 chronology for the EPICA Dome C ice core, Clim. Past, 3, 485-497, doi:10.5194/cp-3-485-2007, 2007.

Petit, J. R., Jouzel, J., Raynaud, D., Barkov, N. I., Barnola, J. M., Basile, I., Bender, M., Chappellaz, J., Davis, M., Delaygue, G., Delmotte, M., Kotlyakov, V. M., Legrand, M., Lipenkov, V. Y., Lorius, C., Pepin, L., Ritz, C., Saltzman, E., and Stievenard, M.: Climate and atmospheric history of the past 420000 years from the Vostok ice core, Antarctica, Nature, 399, 429-436, 1999.

Reyes, A. V., Froese, D. G., and Jensen, B. J. L.: Permafrost response to last interglacial warming: field evidence from nonglaciated Yukon and Alaska, Quaternary Sci. Rev., 29, 32563274, 2010.

Rickaby, R. E. M., Elderfield, H., Roberts, N., Hillenbrand, C. D., Mackensen, A.: Evidence for elevated alkalinity in the glacial Southern Ocean, Paleoceanography, 25, PA1209, doi:10.1029/2009PA001762, 2010.

Romanek, C. S., Grossmass, E. L., and Morse, J. W.: Carbon isotope fractionation in synthetic aragonite and calcite: Effects of temperature and precipitation rate, Geochim. Cosmochim. Ac., 56, 419-430, 1992.

Roth, R. and Joos, F.: Model limits on the role of volcanic carbon emissions in regulating glacial-interglacial $\mathrm{CO}_{2}$ variations, Earth Planet. Sci. Lett., 329-330, 141-149, 2012.

Rubinson, M. and Clayton, R. N.: Carbon-13 fractionation between aragonite and calcite, Geoch. Cosmochim. Ac., 33, 997-1002, 1969.

Ruddiman, W. F.: The anthropogenic greenhouse era began thousands of years ago, Climatic Change, 61, 261-293, 2003.

Sano, Y. and Williams, S.: Fluxes of mantle and subducted carbon along convergent plate boundaries, Geophys. Res. Lett., 23, 2749-2752, 1996.

Schilt, A., Baumgartner, M., Blunier, T., Schwander, J., Spahni, R., Fischer, H., and Stocker, T.: Glacial-interglacial and millennialscale variations in the atmospheric nitrous oxide concentration during the last 800'000 years, Quaternary Sci. Rev., 29, 182-192, 2010.

Schmitt, J., Schneider, R., and Fischer, H.: A sublimation technique for high-precision measurements of $\delta^{13} \mathrm{CO}_{2}$ and mixing ratios of $\mathrm{CO}_{2}$ and $\mathrm{N}_{2} \mathrm{O}$ from air trapped in ice cores, Atmos. Meas. Tech., 4, 1445-1461, doi:10.5194/amt-4-1445-2011, 2011.

Schmitt, J., Schneider, R., Elsig, J., Leuenberger, D., Lourantou, A., Chappellaz, J., Köhler, P., Joos, F., Stocker, T. F., Leuenberger, M., and Fischer, H.: Carbon isotope constraints on the deglacial $\mathrm{CO}_{2}$ rise from ice cores, Science, 336, 711-714, 2012.

Schneider, R.: Quantifying past changes of the global carbon cycle based on d13CO2 measurements in Antarctic ice cores. PhD Thesis, University of Bern, 2011.

Schneider, R. et al:: A reconstruction of atmospheric carbon dioxide and its stable carbon isotopic composition from the penultimate glacial maximum to the glacial inception, doi:10.1594/PANGAEA.817041, 2013, Supplement to: Schneider, R., Schmitt, J., Koehler, P., Joos, F., and Fischer, H. (2013): A reconstruction of atmospheric carbon dioxide and its stable carbon isotopic composition from the penultimate glacial maximum to the glacial inception. PDI-5651, Clim. Past, 2013.

Schneiter, M.: Assimilation of Ocean Tracer Data into the Bern3D Model for Combined Parameter and State Estimation Using 
the Ensemble Kalman Filter, Master thesis, University of Bern, 2011.

Schüpbach, S., Federer, U., Bigler, M., Fischer, H., and Stocker, T. F.: A refined TALDICE-1a age scale from 55 to 112 ka before present for the Talos Dome ice core based on highresolution methane measurements, Clim. Past, 7, 1001-1009, doi:10.5194/cp-7-1001-2011, 2011.

Schüpbach, S., Federer, U., Albani, S., Barbante, C., Stocker, T. F., and Fischer, H.: Sources and transport of dust to East Antarctica: new insights from high-resolution terrestrial and marine aerosol records from the Talos Dome ice core, Clim. Past Discuss., 9, 3321-3370, doi:10.5194/cpd-9-3321-2013, 2013.

Siddall, M., Bard, E., Rohling, E. J., and Hemleben, C.: Sea-level reversal during Termination II, Geology, 34, 817-820, 2006.

Sigman, D. M., Hain, M. P., and Haug, G. H.: The polar ocean and glacial cycles in atmospheric $\mathrm{CO}_{2}$ concentration, Nature, 466, 47-55, 2010.

Smith, H. J., Fischer, H., Mastroianni, D., Deck, B., and Wahlen, M.: Dual modes of the carbon cycle since the Last Glacial Maximum, Nature, 400, 248-250, 1999.

Spero, H. J. and Lea, D. W.: The cause of carbon isotope minimum events on glacial terminations, Science, 296, 522-525, 2002.

Stenni, B., Buiron, D., Frezzotti, M., Albani, S., Barbante, C., Bard, E., Barnola, J. M., Baron, M., Baumgartner, M., Bonazza, M., Capron, E., Castellano, E., Chappellaz, J., Delmonte, B., Falourd, S., Genoni, L., Iacumin, P., Jouzel, J., Kipfstuhl, S., Landais, A., Lemieux-Dudon, B., Maggi, V., MassonDelmotte, V., Mazzola, C., Minster, B., Montagnat, M., Mulvaney, R., Narcisi, B., Oerter, H., Parrenin, F., Petit, J. R., Ritz, C., Scarchilli, C., Schilt, A., Schüpbach, S., Schwander, J., Selmo, E., Severi, M., Stocker, T. F., and Udisti, R.: Expression of the bipolar see-saw in Antarctic climate records during the last deglaciation, Nat. Geosci., 4, 46-49, 2011.
Tarnocai, C., Canadell, J. G., Schuur, E. A. G., Kuhry, P., Mazhitova, G., and Zimov, S.: Soil organic carbon pools in the northern circumpolar permafrost region, Global Biogeochem. Cy., 23, GB2023, doi:10.1029/2008GB003327, 2009.

Tschumi, T., Joos, F., Gehlen, M., and Heinze, C.: Deep ocean ventilation, carbon isotopes, marine sedimentation and the deglacial $\mathrm{CO}_{2}$ rise, Clim. Past, 7, 771-800, doi:10.5194/cp-7-771-2011, 2011.

Visser, K., Thunell, R., and Stott, L.: Magnitude and timing of temperature change in the Indo-Pacific warm pool during deglaciation, Nature, 421, 152-155, 2003.

Zeebe, R. E. and Caldeira, K.: Close mass balance of long-term carbon fluxes from ice-core $\mathrm{CO}_{2}$ and ocean chemistry records, Nat. Geosci., 1, 312-315, 2008.

Zeebe, R. E. and Westbroek, P.: A simple model for $\mathrm{CaCO}_{3}$ saturation state of the ocean: The "Strangelove", the "Neritan" and the "Cretan" Ocean, Geochem. Geophys. Geosys., 4, 1104, doi:10.1029/2003GC000538, 2003.

Zhang, J., Quay, P., and Wilbur, D.: Carbon isotope fractionation during gas-water exchange and dissolution of $\mathrm{CO}_{2}$, Geochim. Cosmochim. Acta, 59, 107-114, 1995.

Zimov, N. S., Zimov, S.A, Zimova, A. E., Zimova, G. M. Chuprynin, V. I., and Chapin, F. S.: Carbon storage in permafrost and soils of the mammoth tundra-steppe biome: role in the global carbon budget, Geophys. Res. Lett., 36, L02502, doi:10.1029/2008GL036332, 2009. 